\title{
Non-biting midges (Diptera: Chironomidae) research in South America: subsidizing biogeographic hypotheses
}

\author{
Fabio Laurindo da Silva ${ }^{1,2 *}$ and Brian D. Farrell ${ }^{1}$ \\ 1 Museum of Comparative Zoology, Department of Organismic and Evolutionary Biology, Harvard University, Cambridge, USA \\ ${ }^{2}$ Laboratory of Aquatic Entomology, Institute of Biological Sciences, Federal University of Bahia, Salvador, Brazil
}

Received 05 July 2016; Accepted 28 November 2016

\begin{abstract}
We present data on Chironomidae (Insecta: Diptera) collected in South America together with results on the mitochondrial DNA diversity within selected megadiverse genera. This work is part of an on-going project on the ancient origin of South American biodiversity using non-biting midges. Collections were made at 42 localities, in March 2014 and February 2015, in a diverse array of habitats, including small streams, rivers, ponds, lakes and bays. In total, 3196 representatives of six subfamilies were collected. Sixty-one genera were identified, containing at least 211 species. The subfamilies Chironominae and Orthocladiinae predominated in all samples. Tanypodinae were often present, but rarely in large numbers. Except for Podonomus pepinellii, reported from Brazil, Podonominae were collected in a few localities in Argentina (Arroyo Lopez, and Arroyo Gutierrez and Gutierrez Lake) and Chile (Llanquihue Lake). Prodiamesinae were only recorded in Chile. Analysis of DNA barcode sequences using neighbor-joining estimation supported 66 species within the selected genera. The chironomid fauna of South America includes multiple genera with worldwide distributions, with Australian, Nearctic and Neotropical components.
\end{abstract}

Key words: Biodiversity / taxonomy / biogeography / Southern Hemisphere / cytochrome oxidase sub-unit I / DNA barcoding

\section{Introduction}

Non-biting midges, belonging to the family Chironomidae, are true flies (order Diptera), and the most widely distributed free-living holometabolous insects (Ferrington, 2008). This cosmopolitan group occurs in all zoogeographical regions of the world, including Antarctica. The immature stages of most species occur in freshwater, but numerous terrestrial or marine species are known (Sæther and Ekrem, 2003). The adult life stage of chironomids is short, and they have limited ability for aerial dispersal compared with many other freshwater insects. Presumably, the great species and habitat diversity in this family is a product of its antiquity and evolutionary plasticity (Ferrington et al., 2008), which not only makes the family a valuable source of indicator species for lentic and lotic aquatic ecosystems, but also an interesting group for phylogenetic and biogeographical analyses (Silva and Ekrem, 2016).

\footnotetext{
*Corresponding author: fabiologia@gmail.com
}

Chironomidae probably originated in the middle Triassic approximately 248-210 million years ago (Cranston et al., 2010). This family comprises at least 10000 species in more than 400 genera (Armitage et al., 1995; Sæther, 2000) and roughly 6200 of these are known to science (P. Ashe, 2014, personal communication). Although the distribution of the species in many genera is relatively well known, detailed analyses of distribution patterns and historical biogeography are rare in chironomids, especially from the austral regions. Historical biogeography is intimately associated with the Chironomidae (Silva and Ekrem, 2016), particularly the austral taxa, which were monographed by Lars Brundin in 1966. Brundin's work had a great impact on biogeography because of the great clarity of his method and the fact that phylogeny played an important role in generating biogeographical hypotheses (Funk, 2004). More recently, chironomids have been used to better understand faunal relationships in southern South America and other southern temperate regions (Cranston et al., 2010; Cranston and Krosch, 2011; Krosch et al., 2011; Krosch and Cranston, 2013). All these studies have in common the idea of a close 
connection among Chironomidae taxa from Australia, New Zealand and southern South America, and reveal the presence of numerous endemic chironomid genera in temperate South America.

The biota of South America always captivated biogeographers because of the interesting distributional patterns exhibited by its flora and fauna (Hooker, 1843; Darwin, 1859; Wallace, 1876). For more than a century, biogeographers have proposed theories to explain the origin and relationships of biotas found in southern South America and other southern temperate regions such as Australia, New Zealand and South Africa. Moreover, numerous theories have attempted to explain the origin and relationships of biotas found in tropical northern and temperate southern South America (Brundin, 1966; Fittkau et al., 1969; Amorim and Tozoni, 1994). Currently, such explanations are challenged by phylogenetic studies, which use molecular data to test whether speciation is driven by dispersal or vicariance (e.g., Brumfield and Capparella, 1996; Klicka and Zink, 1997; Conti et al., 2002; Xiang et al., 2005; Stelbrink et al., 2012; Silva et al., 2015).

Although new species of Chironomidae have recently been described from South America (Silva et al., 2010, 2012, 2014a, 2014b; Oliveira and Silva, 2011; TrivinhoStrixino and Silva, 2011; Dantas and Hamada, 2013; Trivinho-Strixino et al., 2013, 2015; Andersen and Pinho, 2014; Siri and Donato, 2015), none of these studies focused on biological processes such as vicariance, dispersal and extinction in a biogeographical context. To address these questions, a 2-year study, entitled "Understanding the ancient origin of South American biodiversity: a molecular perspective on the evolution and biogeography of non-biting midges (Diptera: Chironomidae)" and supported by the CAPES Foundation, Ministry of Education of Brazil, and the Museum of Comparative Zoology, Department of Organismic and Evolutionary Biology, Harvard University, began in 2014. Here we present a contribution to data on Chironomidae collected during the project, as well as results on the mitochondrial DNA diversity within selected megadiverse genera.

\section{Material and methods}

\section{Study area}

South America is the fourth largest continent of the world $\left(17840000 \mathrm{~km}^{2}\right)$. It is located mostly in the Southern Hemisphere, with a relatively small portion in the Northern Hemisphere. It is bordered on the west by the Pacific Ocean and on the north and east by the Atlantic Ocean; North America and the Caribbean Sea lie to the northwest. This continent is a natural geographic unit and has a varied terrain comprising grasslands, tropical and subtropical rain forests, tropical deciduous forests, caatinga, subantarctic rain forests and mountain vegetation. Climate in South America can be divided into four major climatic regions: tropical, temperate, arid and cold. The mean annual precipitation ranges from 0 to $500 \mathrm{~cm}$. The Neotropical location's complex topography and variety of local weather patterns generate numerous microhabitats, which support a rich flora and fauna with significant numbers of endemic species.

\section{Taxon sampling and identification}

Collections were made at 42 localities, in March 2014 and February 2015 (Table 1, Fig. 1), in a diverse array of habitats, including small streams and ponds to lakes, rivers and bays. The main emphasis was on adult sampling, collected with a sweep net near aquatic systems. A $20 \mathrm{~cm}$ diameter dip-net (mesh size $250 \mu \mathrm{m}$ ) was also used to collect immature stages at some localities. All samples were preserved in the field using $96 \%$ ethanol. In the laboratory, after initial sorting and identification, representatives of every taxon in each sample were slide mounted in Euparal for species identification following the procedure outlined by Pinder (1986, 1989) and Andersen et al. (2013a). Morphological identification was made based on keys of Wiederholm $(1986,1989)$, Epler (2001), Spies et al. (2009), Andersen et al. (2013b), Trivinho-Strixino (2014), original descriptions and eventual examination of type material. Morphological terminology and abbreviations essentially follow Sæther (1980). Voucher specimens are deposited in the Museum of Comparative Zoology (MCZ) at Harvard University, the National Institute of Amazonian Research (INPA) and University Museum, at the Norwegian University of Science and Technology (NTNU-VM).

\section{DNA extraction, amplification, sequencing and alignment}

The more taxonomically and ecologically diverse the species compared in biogeographic studies, the more generally applicable the results will be (Zink, 1996). Therefore, to extend the relevance of the results and verify their suitability as subjects for biogeographical analysis, four megadiverse genera were selected for molecular analyses: Ablabesmyia, Chironomus, Labrundinia and Polypedilum. These are both species rich and widespread in South America. Specimens for DNA were mostly collected as adults and preserved in 80-96\% ethanol and stored dark at $4{ }^{\circ} \mathrm{C}$ before molecular analyses. DNA was extracted from single individuals in a buffered solution with the enzyme proteinase- $\mathrm{K}$ at $56^{\circ} \mathrm{C}$ overnight, following the standard DNeasy Blood \& Tissue Kit (Qiagen, USA), according to the manufacturer's protocol. The final elution volume was $100 \mu \mathrm{L}$. After DNA extraction, the exoskeleton was washed with $96 \%$ ethanol and mounted in Euparal on the same microscope slide as its corresponding head, antennae, wings, legs and abdomen following the procedure outlined by Sæther (1969). Voucher specimens are deposited in the Museum of 
Table 1. Localities and geographic coordinates of chironomid collections in South America in March 2014 and February 2015.

\begin{tabular}{|c|c|c|c|c|c|}
\hline$\overline{\text { Code }}$ & Country & City or Province & Locality & Latitude & Longitude \\
\hline$\overline{1}$ & Argentina & San Carlos de Bariloche & Arroyo Gutierrez & $41^{\circ} 09^{\prime} 36.16^{\prime \prime} \mathrm{S}$ & $71^{\circ} 24^{\prime} 42.40^{\prime \prime} \mathrm{W}$ \\
\hline 2 & Argentina & San Carlos de Bariloche & Arroyo Lopez & $41^{\circ} 05^{\prime} 02.29^{\prime \prime} \mathrm{S}$ & $71^{\circ} 32^{\prime} 50.92^{\prime \prime} \mathrm{W}$ \\
\hline 3 & Argentina & San Carlos de Bariloche & Arroyo Nireco & $41^{\circ} 08^{\prime} 00.92^{\prime \prime} \mathrm{S}$ & $71^{\circ} 17^{\prime} 06.27^{\prime \prime} \mathrm{W}$ \\
\hline 4 & Argentina & San Carlos de Bariloche & Escondido Lake & $41^{\circ} 03^{\prime} 38.00^{\prime \prime} \mathrm{S}$ & $71^{\circ} 34^{\prime} 01.67^{\prime \prime} \mathrm{W}$ \\
\hline 5 & Argentina & San Carlos de Bariloche & Gutierrez Lake & $41^{\circ} 09^{\prime} 59.07^{\prime \prime} \mathrm{S}$ & $71^{\circ} 24^{\prime} 54.46^{\prime \prime} \mathrm{W}$ \\
\hline 6 & Argentina & San Carlos de Bariloche & Nahuel Huapi Lake & $41^{\circ} 07^{\prime} 57.82^{\prime \prime} \mathrm{S}$ & $71^{\circ} 17^{\prime} 37.00^{\prime \prime} \mathrm{W}$ \\
\hline 7 & Argentina & San Carlos de Bariloche & Virgen de las Nieves & $41^{\circ} 07^{\prime} 58.95^{\prime \prime} \mathrm{S}$ & $71^{\circ} 24^{\prime} 52.71^{\prime \prime} \mathrm{W}$ \\
\hline 8 & Argentina & Viedma & Río Negro at outfall & $40^{\circ} 48^{\prime} 00.34^{\prime \prime} \mathrm{S}$ & $62^{\circ} 59^{\prime} 49.28^{\prime \prime} \mathrm{W}$ \\
\hline 9 & Argentina & Viedma & Río Negro & $40^{\circ} 47^{\prime} 56.88^{\prime \prime} \mathrm{S}$ & $63^{\circ} 00^{\prime} 13.68^{\prime \prime} \mathrm{W}$ \\
\hline 10 & Argentina & Viedma & Río Negro near bridge & $40^{\circ} 49^{\prime} 03.41^{\prime \prime} \mathrm{S}$ & $62^{\circ} 58^{\prime} 31.50^{\prime \prime} \mathrm{W}$ \\
\hline 11 & Argentina & Ushuaia & Bahia Lapataia & $54^{\circ} 50^{\prime} 53.38^{\prime \prime} \mathrm{S}$ & $68^{\circ} 29^{\prime} 14.46^{\prime \prime} \mathrm{W}$ \\
\hline 12 & Argentina & Ushuaia & Roca Lake & $54^{\circ} 49^{\prime} 01.43^{\prime \prime} \mathrm{S}$ & $68^{\circ} 36^{\prime} 34.91^{\prime \prime} \mathrm{W}$ \\
\hline 13 & Brazil & Bossoroca & Rio Piratini & $28^{\circ} 31^{\prime} 46.70^{\prime \prime} \mathrm{S}$ & $54^{\circ} 55^{\prime} 10.80^{\prime \prime} \mathrm{W}$ \\
\hline 14 & Brazil & São Luiz Gonzaga & Serra do Caparaó & $20^{\circ} 25^{\prime} 04.00^{\prime \prime} \mathrm{S}$ & $41^{\circ} 48^{\prime} 59.60^{\prime \prime} \mathrm{W}$ \\
\hline 15 & Brazil & Goiás & Córrego dos Buritis & $14^{\circ} 10^{\prime} 05.77^{\prime \prime} \mathrm{S}$ & $47^{\circ} 47^{\prime} 28.49^{\prime \prime} \mathrm{W}$ \\
\hline 16 & Brazil & Goiás & Córrego da Siriema & $14^{\circ} 10^{\prime} 26.48^{\prime \prime} \mathrm{S}$ & $47^{\circ} 49^{\prime} 26.23^{\prime \prime} \mathrm{W}$ \\
\hline 17 & Brazil & Igarassu & Refúgio Charles Darwin & $07^{\circ} 48^{\prime} 56.09^{\prime \prime} \mathrm{S}$ & $34^{\circ} 57^{\prime} 16.15^{\prime \prime} \mathrm{W}$ \\
\hline 18 & Brazil & Manaus & Igarapé Acará & $02^{\circ} 56^{\prime} 29.30^{\prime \prime} \mathrm{S}$ & $59^{\circ} 56^{\prime} 07.40^{\prime \prime} \mathrm{W}$ \\
\hline 19 & Brazil & Manaus & Igarapé Barro Branco & $02^{\circ} 54^{\prime} 32.90^{\prime \prime} \mathrm{S}$ & $59^{\circ} 57^{\prime} 16.11^{\prime \prime} \mathrm{W}$ \\
\hline 20 & Brazil & Mato Grosso do Sul & Rio Miranda & $19^{\circ} 34^{\prime} 30.06^{\prime \prime} \mathrm{S}$ & $57^{\circ} 00^{\prime} 52.40^{\prime \prime} \mathrm{W}$ \\
\hline 21 & Brazil & Presidente Figueiredo & Cachoeira da Suframa & $02^{\circ} 02^{\prime} 17.01^{\prime \prime} \mathrm{S}$ & $60^{\circ} 01^{\prime} 41.46^{\prime \prime} \mathrm{W}$ \\
\hline 22 & Brazil & Presidente Figueiredo & Recanto da Pantera & $02^{\circ} 02^{\prime} 31.38^{\prime \prime} \mathrm{S}$ & $59^{\circ} 50^{\prime} 56.40^{\prime \prime} \mathrm{W}$ \\
\hline 23 & Brazil & Recife & Córrego Oficina Brennand & $08^{\circ} 03^{\prime} 60.42^{\prime \prime} \mathrm{S}$ & $34^{\circ} 58^{\prime} 28.97^{\prime \prime} \mathrm{W}$ \\
\hline 24 & Brazil & Recife & Estação de Aquicultura & $08^{\circ} 01^{\prime} 10.02^{\prime \prime} \mathrm{S}$ & $34^{\circ} 56^{\prime} 42.12^{\prime \prime} \mathrm{W}$ \\
\hline 25 & Brazil & Recife & Lago Apipucos & $08^{\circ} 01^{\prime} 10.00^{\prime \prime} \mathrm{S}$ & $34^{\circ} 56^{\prime} 02.00^{\prime \prime} \mathrm{W}$ \\
\hline 26 & Brazil & Roraima & Igarapé da Jesine & $00^{\circ} 54^{\prime} 47.40^{\prime \prime} \mathrm{N}$ & $59^{\circ} 34^{\prime} 19.70^{\prime \prime} \mathrm{W}$ \\
\hline 27 & Brazil & Roraima & Lagoa Sítio da Ivone & $00^{\circ} 52^{\prime} 57.60^{\prime \prime} \mathrm{N}$ & $59^{\circ} 42^{\prime} 17.40^{\prime \prime} \mathrm{W}$ \\
\hline 28 & Brazil & Roraima & Rio Água Boa & $02^{\circ} 43^{\prime} 32.60^{\prime \prime} \mathrm{N}$ & $60^{\circ} 48^{\prime} 39.80^{\prime \prime} \mathrm{W}$ \\
\hline 29 & Brazil & São Carlos & Córrego do Fazzari & $21^{\circ} 58^{\prime} 08.84^{\prime \prime} \mathrm{S}$ & $47^{\circ} 53^{\prime} 10.21^{\prime \prime} \mathrm{W}$ \\
\hline 30 & Brazil & São Carlos & Córrego do Espraiado & $21^{\circ} 58^{\prime} 12.35^{\prime \prime} \mathrm{S}$ & $47^{\circ} 52^{\prime} 16.42^{\prime \prime} \mathrm{W}$ \\
\hline 31 & Brazil & São Carlos & Córrego do Monjolinho & $21^{\circ} 59^{\prime} 09.51^{\prime \prime} \mathrm{S}$ & $47^{\circ} 52^{\prime} 40.46^{\prime \prime} \mathrm{W}$ \\
\hline 32 & Brazil & São Carlos & Parque Ecológico & $21^{\circ} 59^{\prime} 09.84^{\prime \prime} \mathrm{S}$ & $47^{\circ} 52^{\prime} 32.34^{\prime \prime} \mathrm{W}$ \\
\hline 33 & Brazil & São Carlos & Represa do Fazzari & $21^{\circ} 58^{\prime} 17.87^{\prime \prime} \mathrm{S}$ & $47^{\circ} 53^{\prime} 14.92^{\prime \prime} \mathrm{W}$ \\
\hline 34 & Brazil & São Carlos & UFSCar & $21^{\circ} 59^{\prime} 00.51^{\prime \prime} \mathrm{S}$ & $47^{\circ} 52^{\prime} 42.39^{\prime \prime} \mathrm{W}$ \\
\hline 35 & Brazil & Tamandaré & REBio Saltinho & $08^{\circ} 43^{\prime} 24.88^{\prime \prime} \mathrm{S}$ & $35^{\circ} 11^{\prime} 11.23^{\prime \prime} \mathrm{W}$ \\
\hline 36 & Chile & Puerto Montt & Lago Chapo & $41^{\circ} 25^{\prime} 51.17^{\prime \prime} \mathrm{S}$ & $72^{\circ} 34^{\prime} 11.48^{\prime \prime} \mathrm{W}$ \\
\hline 37 & Chile & Puerto Montt & Rio Chamiza & $41^{\circ} 26^{\prime} 04.85^{\prime \prime} \mathrm{S}$ & $72^{\circ} 35^{\prime} 09.43^{\prime \prime} \mathrm{W}$ \\
\hline 38 & Chile & Puerto Varas & Lago Todos los Santos & $41^{\circ} 07^{\prime} 55.66^{\prime \prime} \mathrm{S}$ & $72^{\circ} 23^{\prime} 59.30^{\prime \prime} \mathrm{W}$ \\
\hline 39 & Chile & Puerto Varas & Laguna la Poza & $41^{\circ} 16^{\prime} 40.22^{\prime \prime} \mathrm{S}$ & $72^{\circ} 51^{\prime} 17.81^{\prime \prime} \mathrm{W}$ \\
\hline 40 & Chile & Puerto Varas & Llanquihue Lake 1 & $41^{\circ} 16^{\prime} 37.51^{\prime \prime} \mathrm{S}$ & $72^{\circ} 51^{\prime} 11.71^{\prime \prime} \mathrm{W}$ \\
\hline 41 & Chile & Puerto Varas & Llanquihue Lake 2 & $41^{\circ} 18^{\prime} 53.55^{\prime \prime} \mathrm{S}$ & $72^{\circ} 58^{\prime} 56.40^{\prime \prime} \mathrm{W}$ \\
\hline 42 & Chile & Puerto Varas & Rio Petrohué & $41^{\circ} 08^{\prime} 27.62^{\prime \prime} \mathrm{S}$ & $72^{\circ} 24^{\prime} 19.58^{\prime \prime} \mathrm{W}$ \\
\hline
\end{tabular}

Comparative Zoology (MCZ) at Harvard University and University Museum, National Institute of Amazonian Research (INPA) and University Museum, at the Norwegian University of Science and Technology (NTNU-VM).

PCR amplification was conducted in $25 \mu \mathrm{L}$ reactions and contained $2 \mu \mathrm{L}$ DNA template (concentration not measured), $2.5 \mu \mathrm{L} 5 \times$ buffer, $2 \mu \mathrm{L} \mathrm{MgCl}_{2}$ in $25 \mu \mathrm{M}$ concentration, $0.2 \mu \mathrm{L}$ of dNTPs in $10 \mathrm{mM}$ concentration, $1 \mu \mathrm{L}$ of each of the universal standard barcode primers (Folmer et al., 1994) LCO1490 (50-GGTCAACAAA TCATAAAGATATTG-30) and HCO2198 (50-TAA ACTTCAGGGTGACCAAAAAATC-30), in $10 \mu \mathrm{M}$ concentration, $0.2 \mu \mathrm{L}$ of HotStarTaq (all from Qiagen, Germany) and $16.1 \mu \mathrm{L}$ of ddH2O. Amplifications for the COI region were performed in a thermocycler with an initial denaturation step at $95^{\circ} \mathrm{C}$ for $15 \mathrm{~min}$, followed by five cycles at $94^{\circ} \mathrm{C}$ for $30 \mathrm{~s}, 45^{\circ} \mathrm{C}$ for $30 \mathrm{~s}, 72^{\circ} \mathrm{C}$ for $1 \mathrm{~min}$, followed by 35 cycles at $94{ }^{\circ} \mathrm{C}$ for $30 \mathrm{~s}, 51^{\circ} \mathrm{C}$ for $30 \mathrm{~s}, 72^{\circ} \mathrm{C}$ for $1 \mathrm{~min}$ and one cycle at $72^{\circ} \mathrm{C}$ for $5 \mathrm{~min}$, and then held at $4{ }^{\circ} \mathrm{C}$.

The PCR products were purified using shrimp alkaline phosphatase and exonuclease I (USB Corp., USA). For bidirectional sequencing, we used the ABI PRISM BigDye Terminator version 3.1 Cycle Sequencing Kit (Life Technologies, USA), and cycle sequencing reactions were performed on ABI PRISM 3130xl or 3730xl automated sequencers (Life Technologies, USA) at Harvard University. All sequences generated in this study are available through the dataset "Megadiverse Chironomidae 


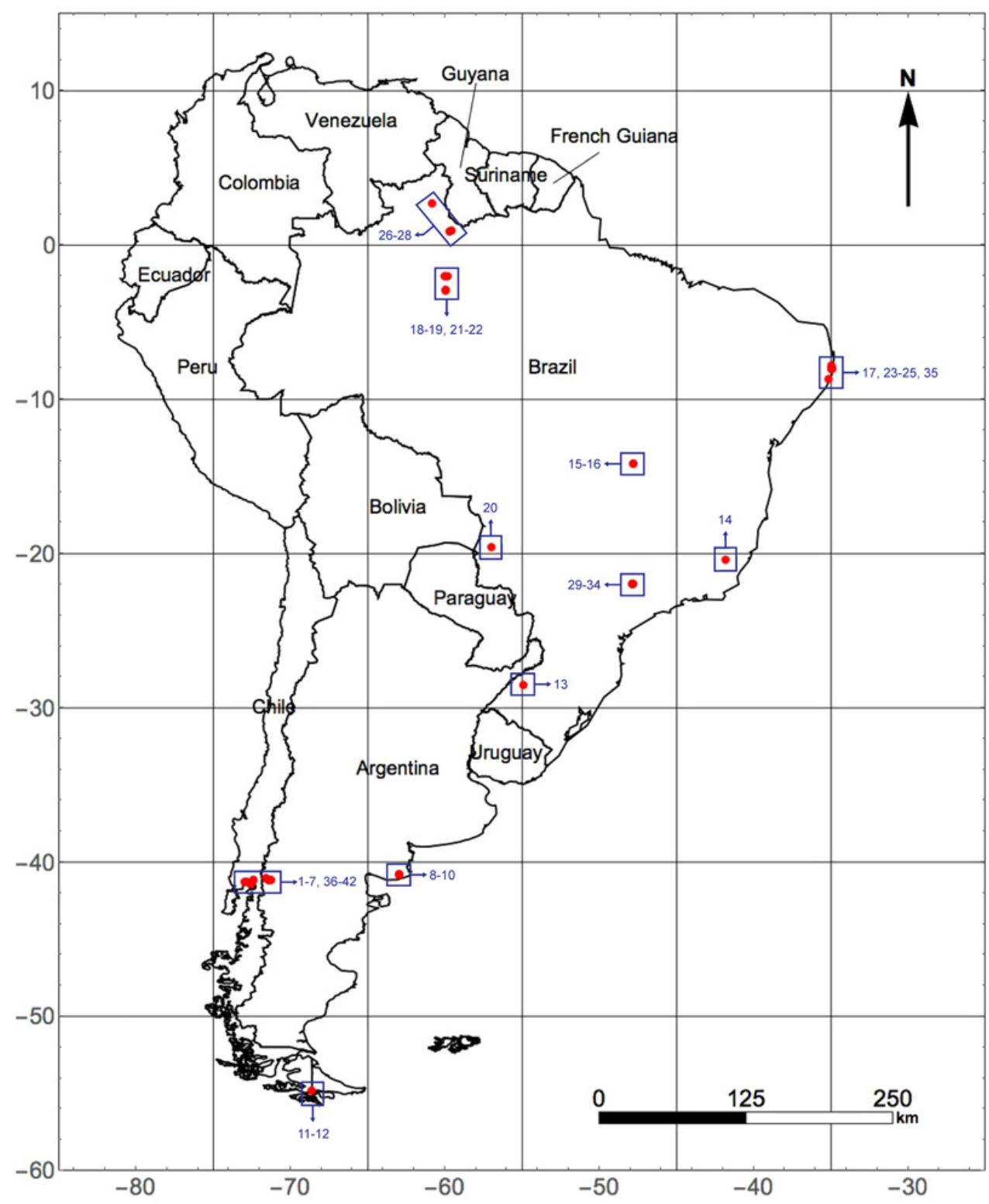

Fig. 1. Map of South America showing sampling sites in Argentina, Brazil and Chile (red dots). Some sites overlap due to their proximity and the map scale. Blue numbers indicate sampling localities. See Table 1 for more details.

DNA barcoding 2016 (DS-MDCBAR)" on BOLD, DOI: dx.doi.org/10.5883/DS-MDCBAR. Sequences were assembled and edited using Geneious 8.1.5 (Drummond et al., 2010), checked for stop codons and aligned as translated amino acids using the Muscle algorithm (Edgar, 2004) on amino acids as implemented in MEGA7 (Kumar et al., 2016). The alignment was trivial as no indels or introns were observed in the sequences.

\section{Data analysis}

A neighbor-joining (NJ) tree was produced in MEGA7 using the Kimura-2-parameter (K2P) model (Kimura, 1980), to make our results comparable with most other DNA barcode studies on insects. Bootstrap analysis used
1000 pseudoreplicates (Felsenstein, 1985) and the "pairwise deletion" option of missing data. The nucleotide statistics and pairwise distances were also calculated based on the K2P model in MEGA7. Tree graphics were produced using TreeView (Page, 1996).

\section{Results}

In total, 3196 representatives of six subfamilies were collected (Table 2). Sixty-one genera have been identified, containing at least 211 species. At least 11 additional species were collected that could not be assigned to described genera and were identified as Chironominae sp. 1-3 and Orthocladiinae sp. 1-8. Chironomidae was represented in the tropical northern South America by 
Table 2. Chironomid taxa collected in South America, March 2014 and February 2015.

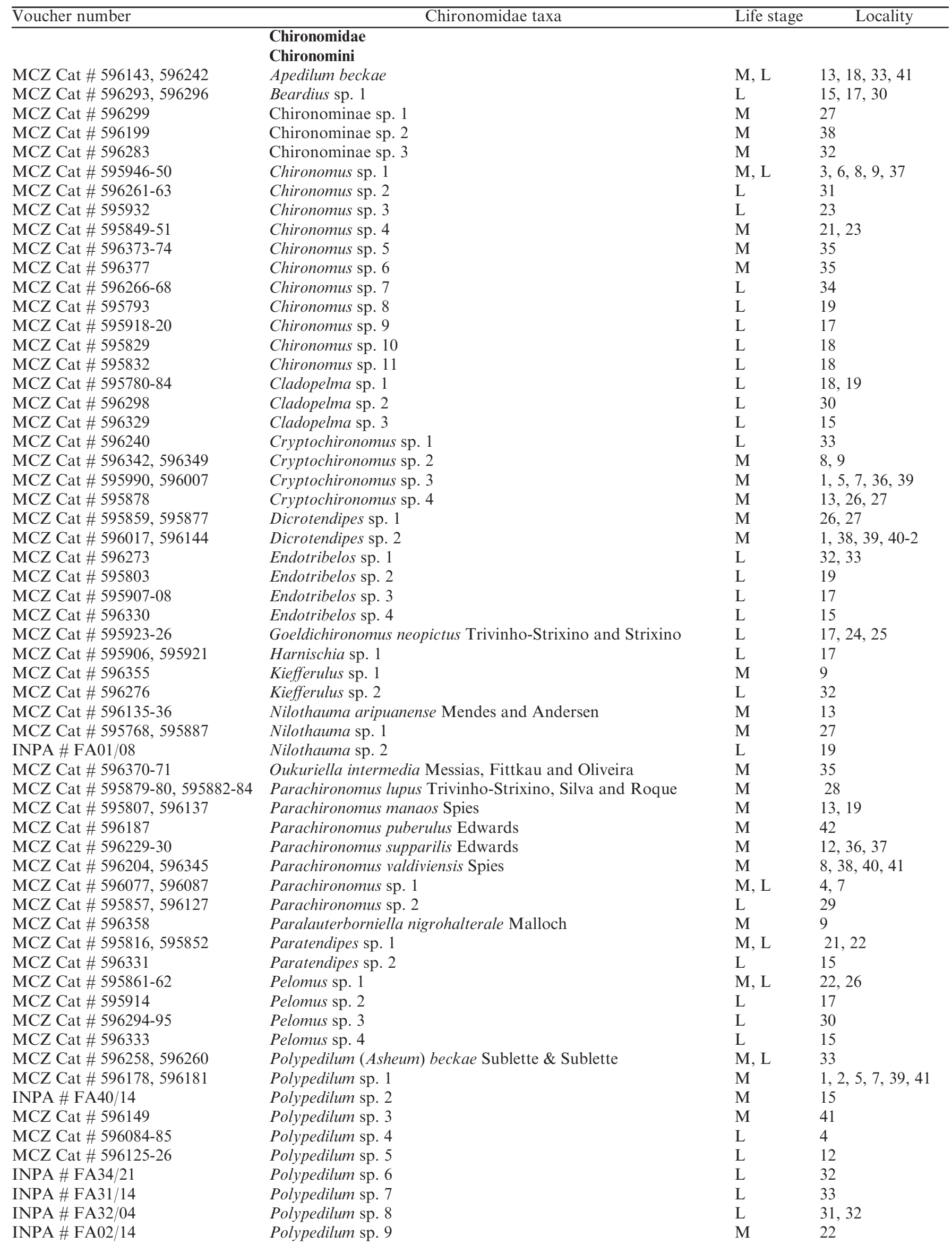


Table 2. (Contd.)

\begin{tabular}{|c|c|c|c|}
\hline Voucher number & Chironomidae taxa & Life stage & Locality \\
\hline$\overline{\text { INPA \# FA32/05 }}$ & Polypedilum sp. 10 & $\mathrm{~L}$ & 31 \\
\hline INPA \# FA01/37 & Polypedilum sp. 11 & $\mathrm{~L}$ & 19 \\
\hline INPA \# FA03/04 & Polypedilum sp. 12 & $\mathrm{~L}$ & 18 \\
\hline INPA \# FA01/42 & Polypedilum sp. 13 & $\mathrm{~L}$ & 19 \\
\hline INPA \# FA23/10 & Polypedilum sp. 14 & M & 13 \\
\hline INPA \# FA44/04 & Polypedilum sp. 15 & $\mathrm{~L}$ & 10 \\
\hline MCZ Cat \# 595895 & Polypedilum sp. 16 & M & 27 \\
\hline INPA \# FA06/15 & Polypedilum sp. 17 & M & 26 \\
\hline INPA \# FA40/18 & Polypedilum sp. 18 & $\mathrm{~L}$ & 15 \\
\hline INPA \# FA02/16 & Polypedilum sp. 19 & $\mathrm{~L}$ & 22 \\
\hline INPA \# FA31/24 & Polypedilum sp. 20 & M & 33 \\
\hline INPA \# FA02/05 & Polypedilum sp. 21 & $\mathrm{~L}$ & 22 \\
\hline MCZ Cat \# 595853-54 & Polypedilum sp. 22 & M & 21 \\
\hline MCZ Cat \# 596189-92 & Polypedilum sp. 23 & M & 38,42 \\
\hline INPA \# FA04/24 & Polypedilum sp. 24 & M & 38 \\
\hline INPA \# FA46/09 & Polypedilum sp. 25 & M & 35 \\
\hline INPA \# FA40/16 & Polypedilum sp. 26 & $\mathrm{~L}$ & 15,16 \\
\hline MCZ Cat \# 595894 & Polypedilum sp. 27 & $\mathrm{M}, \mathrm{L}$ & 28 \\
\hline MCZ Cat \# 596354 & Saetheria sp. 1 & $\mathrm{M}$ & 8 \\
\hline MCZ Cat \# 595763 & Stenochironomus sp. 1 & $\mathrm{~L}$ & 19 \\
\hline MCZ Cat \# 595909 & Stenochironomus sp. 2 & $\mathrm{~L}$ & 17 \\
\hline MCZ Cat \# 96128 & $\begin{array}{l}\text { Xestochironomus sp. } 1 \\
\text { Pseudochironomini }\end{array}$ & M & 13 \\
\hline MCZ Cat \# 595888, 596346 & Pseudochironomus sp. 1 & M & 8,28 \\
\hline MCZ Cat \# 595826-27 & Riethia manauara Neubern, Trivinho-Strixino and Silva & $\mathrm{L}$ & 18 \\
\hline MCZ Cat \# 595994-96 & Riethia truncatocaudata Edwards & $\mathrm{L}$ & 1,5 \\
\hline MCZ Cat \# 596030 & $\begin{array}{l}\text { Riethia } \text { sp. } 1 \\
\text { Tanytarsini }\end{array}$ & $\mathrm{M}$ & 28 \\
\hline NTNU-VM \# 150005, 150006 & Caladomyia hoefleri Reiff & M & 28 \\
\hline NTNU-VM \# 150010 & Caladomyia kapilei Trivinho-Strixino & M & 28 \\
\hline NTNU-VM \# 150009, 150049 & Caladomyia ortoni Säwedal & M & 28,32 \\
\hline NTNU-VM \# 149999, 150000 & Caladomyia sp. 1 & M & 26 \\
\hline NTNU-VM \# 150007 & Caladomyia sp. 2 & M & 28 \\
\hline NTNU-VM \# 150008 & Caladomyia sp. 3 & M & 28 \\
\hline MCZ Cat \# 595809, 596031-2 & Cladotanytarsus sp. 1 & $\mathrm{~L}$ & $1,7,22$ \\
\hline MCZ Cat \# 595889-90 & Nandeva sp. 1 & M & 22 \\
\hline INPA \# FA36/05 & Nandeva sp. 2 & M & 29 \\
\hline MCZ Cat \# 595801-02 & Rheotanytarsus sp. 1 & $\mathrm{~L}$ & 19 \\
\hline MCZ Cat \# 595885-86 & Rheotanytarsus sp. 2 & M & 28 \\
\hline MCZ Cat \# 596305 & Rheotanytarsus sp. 3 & $\mathrm{~L}$ & 29 \\
\hline MCZ Cat \# 595765 & Stempellinella sp. 1 & $\mathrm{~L}$ & 19 \\
\hline NTNU-VM \# 150026 & Tanytarsus clivosus Reiss & $\mathrm{M}$ & 5 \\
\hline MCZ Cat \# 596088, 596324 & Tanytarsus fastigatus Reiss & M & $4,5,7,40$ \\
\hline NTNU-VM \# 150038-41 & Tanytarsus hamatus Reiss & M & 37 \\
\hline NTNU-VM \# 150033-34 & Tanytarsus jacaretingensis Sanseverino & M & 13 \\
\hline NTNU-VM \# 150001 & Tanytarsus kiche Vinogradova, Riss and Spies & M & 26 \\
\hline NTNU-VM \# 150045-46 & Tanytarsus longitubuli Trivinho-Strixino, Wiedenbrug and Silva & $\mathrm{M}, \mathrm{L}$ & 32,33 \\
\hline NTNU-VM \# 150044 & Tanytarsus obiriciae Trivinho-Strixino and Sonoda & $\mathrm{M}, \mathrm{L}$ & 33 \\
\hline NTNU-VM \# 149978 & Tanytarsus rhabdomantis Trivinho-Strixino and Strixino & $\mathrm{M}, \mathrm{L}$ & 21,22 \\
\hline NTNU-VM \# 150011 & Tanytarsus riopreto Fittkau and Reiss & $\mathrm{M}$ & 28 \\
\hline MCZ Cat \# 596206, 596256 & Tanytarsus sp. 1 & $\mathrm{~L}$ & 15 \\
\hline MCZ Cat \# 596337, 596338 & Tanytarsus sp. 2 & $\mathrm{~L}$ & 16 \\
\hline MCZ Cat \# 595785, 595828 & Tanytarsus sp. 3 & $\mathrm{~L}$ & 18,19 \\
\hline NTNU-VM \# 149976, 149979 & Tanytarsus sp. 4 & $\mathrm{M}$ & 22 \\
\hline NTNU-VM \# 149980 & $\begin{array}{l}\text { Tanytarsus sp. } 5 \\
\text { Orthocladiinae }\end{array}$ & M & 22 \\
\hline MCZ Cat \# 596379 & Allocladius quadrus Andersen, Sæther et Mendes & M & 11 \\
\hline MCZ Cat \# 596108-09 & Allocladius sp. 1 & $\mathrm{M}$ & 2 \\
\hline MCZ Cat \# 596076 & Botryocladius sp. 1 & $\mathrm{~L}$ & 7 \\
\hline MCZ Cat \# 595817, 595917 & Corynoneura sp. 1 & $\mathrm{~L}$ & 17,22 \\
\hline MCZ Cat \# 596035, 596057 & Corynoneura sp. 2 & $\mathrm{M}, \mathrm{L}$ & $1,7,9,41$ \\
\hline INPA \# FA23/G & Corynoneura sp. 3 & $\mathrm{M}$ & 13 \\
\hline MCZ Cat \# 596335, 596340 & Corynoneura sp. 4 & $\mathrm{~L}, \mathrm{M}$ & 15,16 \\
\hline
\end{tabular}


Table 2. (Contd.)

\begin{tabular}{|c|c|c|c|}
\hline Voucher number & Chironomidae taxa & Life stage & Locality \\
\hline 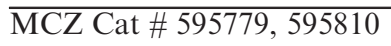 & Cricotopus sp. 1 & $\mathrm{~L}$ & $19,22,21$ \\
\hline MCZ Cat \# 595954-55 & Cricotopus sp. 2 & $\mathrm{M}, \mathrm{P}$ & $1,3,5,6,7,9$ \\
\hline MCZ Cat \# 596139, 596142 & Cricotopus sp. 3 & M & 13 \\
\hline MCZ Cat \# 596166-67 & Cricotopus sp. 4 & M & $37,39,40,41$ \\
\hline MCZ Cat \# 596339 & Cricotopus sp. 5 & $\mathrm{~L}$ & 16 \\
\hline MCZ Cat \# 595956, 596066 & Eukiefferiella sp. 1 & $\mathrm{M}, \mathrm{L}$ & $2,3,7,42$ \\
\hline MCZ Cat \# 596195, 596208 & Ferringtonia patagonica Edwards & M & 38,42 \\
\hline MCZ Cat \# 596208 & Ichthyocladius sp. 1 & $\mathrm{~L}$ & 15 \\
\hline MCZ Cat \# 596380 & Limnophyes sp. 1 & $\mathrm{M}, \mathrm{L}$ & $6,7,11,41$ \\
\hline INPA \# FA25/L & Lipurometriocnemus sp. 1 & M & $36,38,39,41$ \\
\hline MCZ Cat \# 595863-64 & Lopescladius (Cordiella) sp. 1 & M & 26 \\
\hline MCZ Cat \# 595867-68 & Lopescladius (Lopescladius) sp. 1 & M & 26 \\
\hline MCZ Cat \# 596232 & Mesosmittia sp. 1 & M & 36 \\
\hline MCZ Cat \# 595814, 595858 & Orthocladiinae sp. 1 & $\mathrm{~L}$ & 22 \\
\hline MCZ Cat \# 595969, 595974 & Orthocladiinae sp. 2 & $\mathrm{~L}$ & 6 \\
\hline MCZ Cat \# 595997, 595999 & Orthocladiinae sp. 3 & $\mathrm{~L}$ & 5,7 \\
\hline MCZ Cat \# 596110, 596111 & Orthocladiinae sp. 4 & M & 2 \\
\hline MCZ Cat \# 596138 & Orthocladiinae sp. 5 & M & 13 \\
\hline MCZ Cat \# 596186 & Orthocladiinae sp. 6 & M & 39 \\
\hline MCZ Cat \# 596213, 596218 & Orthocladiinae sp. 7 & M & 36,37 \\
\hline MCZ Cat \# 596034, 596036 & Orthocladiinae (Paracladius?) sp. 8 & $\mathrm{~L}$ & 1 \\
\hline MCZ Cat \# 596104-05 & Orthocladius sp. 1 & $\mathrm{M}, \mathrm{P}$ & $2,6,7,41$ \\
\hline MCZ Cat \# 596194 & Parakiefferiella sp. 1 & $\mathrm{M}, \mathrm{L}$ & $2,39,42$ \\
\hline MCZ Cat \# 595981 & Parametriocnemus sp. 1 & $\mathrm{~L}$ & 3,6 \\
\hline MCZ Cat \# 596378 & Parapsectrocladius acuminatus Edwards & M & 11 \\
\hline MCZ Cat \# 596011, 596174 & Parapsectrocladius longistylus Cranston & M & 5,41 \\
\hline MCZ Cat \# 595951-53 & Parapsectrocladius sp. 1 & $\mathrm{~L}, \mathrm{P}$ & 3 \\
\hline MCZ Cat \# 595804-06 & Pseudosmittia sp. 1 & $\mathrm{~L}$ & 19 \\
\hline MCZ Cat \# 596251 & Thienemanniella sancticaroli & M & 7 \\
\hline MCZ Cat \# 596058 & Thienemanniella sp. 1 & $\mathrm{~L}$ & 33 \\
\hline MCZ Cat \# 596325 & Thienemanniella sp. 2 & $\mathrm{~L}$ & 15 \\
\hline \multirow[t]{3}{*}{ INPA \# FA02/10 } & Ubatubaneura sp. 1 & $\mathrm{~L}$ & 22 \\
\hline & Podonominae & & \\
\hline & Podonomini & & \\
\hline MCZ Cat \# 596095-99 & Parochlus araucanus Brundin & M & 2 \\
\hline MCZ Cat \# 595941-45 & Podonomus pepinellii Roque and Trivinho-Strixino & $\mathrm{L}$ & 14 \\
\hline MCZ Cat \# 596100-02 & Podonomus sp. 1 & $\mathrm{~L}$ & 2 \\
\hline MCZ Cat \# 596000-03 & Podonomus sp. 2 & $\mathrm{~L}$ & 5 \\
\hline MCZ Cat \# 596025 & Podonomus sp. 3 & $\mathrm{~L}$ & 1 \\
\hline \multirow[t]{2}{*}{ MCZ Cat \# 596152-53 } & Podonomus sp. 4 & $\mathrm{~L}$ & 41 \\
\hline & Prodiamesinae & & \\
\hline \multirow[t]{3}{*}{ MCZ Cat \# 596170} & Monodiamesa mariae Andersen & M & 41 \\
\hline & Tanypodinae & & \\
\hline & Clinotanypodini & & \\
\hline MCZ Cat \# 596272 & Clinotanypus sp. 1 & $\mathrm{~L}$ & 32 \\
\hline \multirow[t]{2}{*}{ MCZ Cat \# 595818-19 } & Coelotanypus sp. 1 & $\mathrm{~L}$ & 18 \\
\hline & Fittkauimyiini & & \\
\hline MCZ Cat \# 595771-75 & Fittkauimyia sp. 1 & $\mathrm{~L}$ & 19 \\
\hline \multirow[t]{2}{*}{ MCZ Cat \# 596290-92 } & Fittkauimyia sp. 2 & $\mathrm{~L}$ & 30 \\
\hline & Macropelopiini & & \\
\hline MCZ Cat \# 596210 & Alotanypus vittiger Edwards & $\mathrm{M}$ & 37 \\
\hline MCZ Cat \# 596211 & Alotanypus sp. 1 & M & 37 \\
\hline INPA \# FA18/11 & Alotanypus sp. 2 & M & 4,5 \\
\hline INPA \# FA22 $/ 8$ & Alotanypus sp. 3 & M & 2 \\
\hline \multirow[t]{2}{*}{ MCZ Cat \# 596051- 596052} & Apsectrotanypus sp. 1 & $\mathrm{~L}$ & 7 \\
\hline & Pentaneurini & & \\
\hline MCZ Cat \# 596318 & Ablabesmyia sp. 1 & $\mathrm{~L}$ & 15 \\
\hline MCZ Cat \# 596300-02 & Ablabesmyia sp. 2 & $\mathrm{~L}$ & $15,17,29$ \\
\hline MCZ Cat \# 595761 & Ablabesmyia sp. 3 & $\mathrm{~L}$ & 18 \\
\hline MCZ Cat \# 596317 & Ablabesmyia sp. 4 & $\mathrm{~L}$ & 15 \\
\hline MCZ Cat \# 596200-03 & Ablabesmyia sp. 5 & $\mathrm{M}, \mathrm{L}$ & $1,2,4,5,7,36,38$ \\
\hline MCZ Cat \# 596362, 596363 & Ablabesmyia sp. 6 & $\mathrm{M}$ & 12 \\
\hline MCZ Cat \# 595764, 595767 & Ablabesmyia sp. 7 & $\mathrm{~L}$ & 18 \\
\hline
\end{tabular}


Table 2. (Contd.)

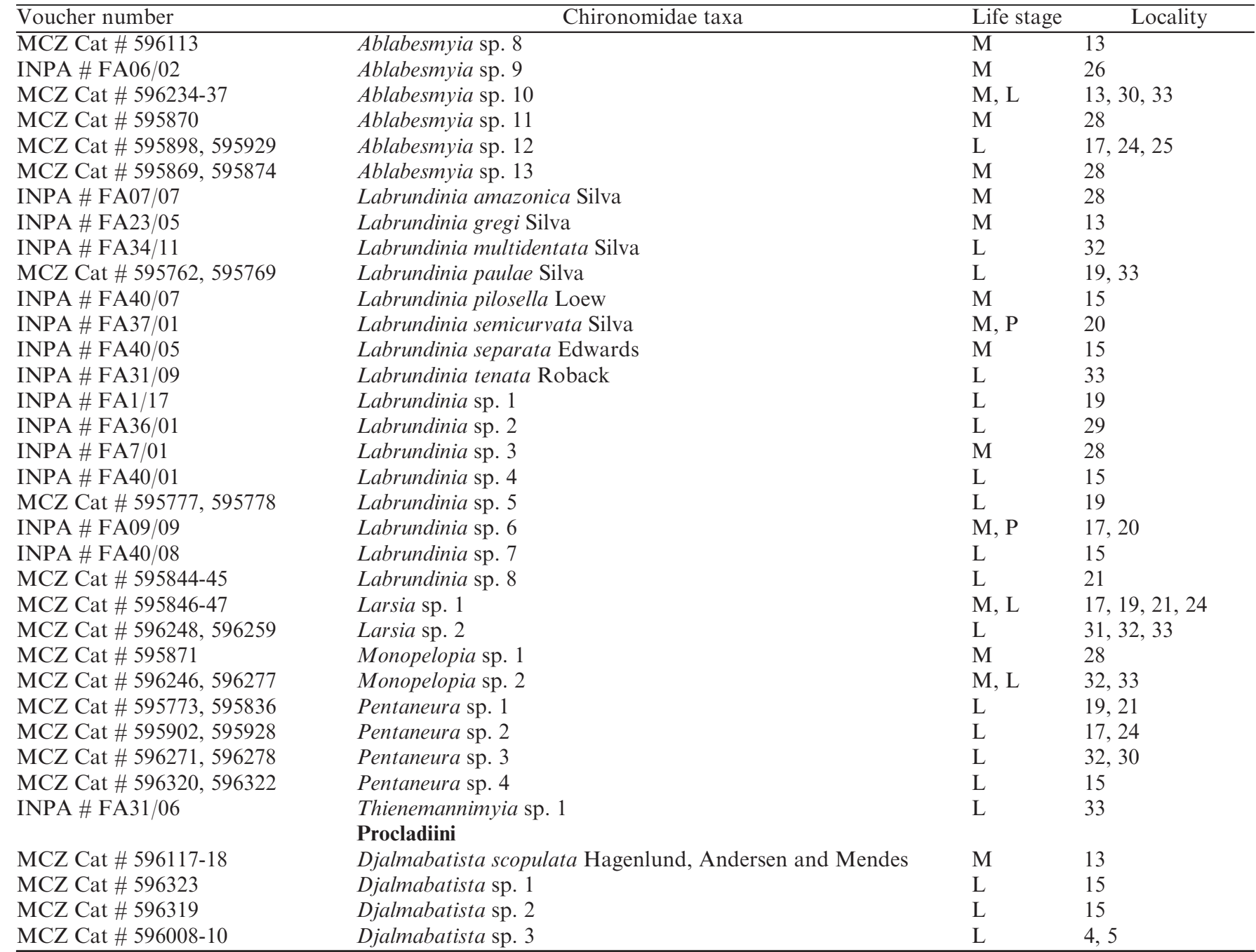

Data in the "Voucher number" column refer partially to what is housed at INPA, MCZ and NTNU-VM only, and for some species this is less than the full material examined in the present study.

M, male; L, larva; P, pupal exuviae. Sampling localities according to Table 1.

151 species, while the temperate southern comprised 57; only three species were common to both regions. The subfamilies Chironominae and Orthocladiinae predominated in all samples. Tanypodinae were present, but rarely in large numbers. Podonominae were collected in a few localities. Prodiamesinae were recorded only in Chile.

\section{Chironominae}

Chironominae is the largest subfamily in terms of described species. This group dominates samples from tropical and subtropical lowlands, with immature stages occurring in a wide range of freshwater habitats, including brackish and marine waters (Ashe et al., 1987). Chironominae is subdivided into three tribes: Chironomini, Pseudochironomini and Tanytarsini.

Chironomini was represented by at least 20 genera, comprising at least 83 species. Polypedilum was the most widespread and rich in species. At least 27 species were collected, about half of which have previously been recorded from the Neotropical Region (Spies and Reiss, 1996). Polypedilum is one of the largest chironomid genera containing about 440 described species (Sæther et al., 2010). Larvae of Polypedilum occur in nearly all types of still and flowing waters. A few species are also found in bromeliad tanks (Epler et al., 2013). Other commonly sampled Chironominae were Chironomus; with 11 species, it was the second most speciose Chironomini genus. Chironomus is a cosmopolitan genus with several hundred species. Numerous species of this group are very abundant in heavily polluted standing or running waters, whereas some species commonly colonize small water bodies such as fish breeding tanks, where they complete their life cycle in a few days (Correia et al., 2013). Spies and Reiss (1996) catalogued 19 species from the Neotropical region. However, this number clearly represents outdated knowledge and significantly underestimates real diversity of 
Chironomus in the Neotropics, considering that several new species have been described more recently (Correia and Trivinho-Strixino, 2005, 2007; Correia et al., 2005, 2006, 2013).

The tribe Pseudochironomini was represented by Pseudochironomus sp. 1, Riethia manauara Neubern, Trivinho-Strixino and Silva, $R$. truncatocaudata (Edwards) and an undescribed species of the latter genus. Larvae of Riethia inhabit the bottom of lotic and lentic systems associated with sandy and fine particulate organic matter (Neubern et al., 2011). In the Neotropics, pupal exuviae of Riethia have been recognized by Ospina-Torres (1992), Wiedenbrug (2000) and Roque et al. (2004) from disparate sites in Brazil. The group has close relatives recorded from Australasia, such expanded distribution seems to support Freeman's $(1959,1961)$ hypothesis that Riethia is an ancient Southern Hemisphere group, including the related Aedokritus, Megacentron and Manoa.

Tanytarsini was represented by six genera: Caladomyia, Cladotanytarsus, Nandeva, Rheotanytarsus, Stempellinella and Tanytarsus. The latter was represented by nine species and five related undescribed species. This genus is one of the most species rich genera of Chironomidae in the Neotropical region (Trivinho-Strixino et al., 2015). The identification of adults of Tanytarsus is problematical due to the large interspecific variation in the genitalic morphology (Ekrem and Reiss, 1999). Despite this drawback, recent years have seen increased interest concerning the taxonomy of the group in the Neotropical region (Sanseverino and Trivinho-Strixino, 2010; Sanseverino et al., 2010; Trivinho-Strixino et al., 2015).

\section{Orthocladiinae}

Orthocladiinae is the second largest subfamily, with the greatest diversity of ecological requirements (Ashe and Cranston, 1990). There is no accepted division of Orthocladiinae into tribes. In our study, the subfamily was represented by 18 genera, comprising at least 39 species. Cricotopus, represented by five morphospecies, was the most widespread orthoclad. The genus is one of the largest in the Orthocladiinae, comprising five subgenera, with worldwide distribution (Cranston et al., 1989; Ashe and O'Connor, 2009). Another commonly found Orthocladiinae was Corynoneura, represented by four morphospecies recorded from several localities. The genus belongs to the Corynoneura group, which is a large and ecologically diverse clade containing over 180 species of non-biting midges worldwide and at least 42 in the Neotropical region (Silva and Wiedenbrug, 2014). Additionally, it is important to point out the first record of Lipurometriocnemus in southern South America. This genus was described from St. Vincent and St. Lucia in the British West Indies and later recorded from Brazil and North America (Andersen et al., 2016). In our study, Lipurometriocnemus was recorded from four localities in Chile, representing the southernmost occurrence of this genus.

\section{Podonominae}

Podonominae is a subfamily distributed worldwide, and currently represented by 15 genera. In our study, Podonominae was represented by Parochlus araucanus Brundin, and Podonomus pepinellii Roque and TrivinhoStrixino. Four larval morphospecies of Podonomus could not be ascribed to any of the previously described species, which is expected since only few larval associations have been made. So far, $P$. pepinellii is the only species described from high mountains in Brazil, which can be attributed to the largely cold-stenothermic preference exhibited by most podonomines. Parochlus is the most widespread and rich genus within Podonominae. The genus is very diverse in the southern temperate zone, from sub- and true Antarctic, and in Australia, New Zealand and South America. According to Cranston et al. (2010), Parochlus originated in low latitudes, moving into the Andes as they rose. The migration of a single widespread species, $P$. kiefferi, into the Northern Hemisphere may be attributable to dispersal events from the Neotropical region through the nearly continuous chain of mountains that extend from southern Chile to Arctic Canada (Cranston et al., 2010). Therefore, it is expected that evidence of dispersal in Parochlus will be reflected as a series of closely related species with older lineages found toward the south, with progressively younger lineages present further north, with $P$. kiefferi as sister to the northernmost Neotropical Parochlus (Cranston et al., 2010).

\section{Prodiamesinae}

Prodiamesinae is a small subfamily comprising four genera: Compteromesa, Monodiamesa, Odontomesa and Prodiamesa. Here Prodiamesinae was represented only by one species from Chile, Monodiamesa mariae Andersen. No genera of Prodiamesinae are known to have a worldwide distribution (Ashe et al., 1987), but Monodiamesa is the most widespread and rich in species genus. The presence of Monodiamesa, as well as Prodiamesa in the Neotropical Region may be attributable to dispersal events from the Northern Hemisphere through the North American Rockies and the mountains of Central America, and down the Andes Mountains (Andersen, 1996). In contrast to Parochlus (Podonominae), it is expected that dispersal in Monodiamesa will be reflected as a sequence of closely related species, with older lineages found towards the north, and progressively younger lineages present further south.

\section{Tanypodinae}

Tanypodinae is the third most speciose subfamily in the Chironomidae, with species distributed widely across most of the globe, occupying numerous habits including small streams and ponds to lakes and bays (Silva et al., 2011). 
Table 3. Variable and informative sites, and average nucleotide composition in the aligned COI gene sequences.

\begin{tabular}{|c|c|c|c|c|c|c|c|c|}
\hline Nucleotide position & Variable site (\%) & Informative site $(\%)$ & $\mathrm{T}(\%)$ & $\mathrm{C}(\%)$ & $\mathrm{A}(\%)$ & $\mathrm{G}(\%)$ & $\mathrm{AT}(\%)$ & $\mathrm{GC}(\%)$ \\
\hline 1 st & 21.6 & 22.3 & 27.4 & 16.3 & 27.4 & 28.9 & 54.8 & 45.2 \\
\hline 2nd & 6.8 & 4.0 & 43.1 & 26.8 & 13.9 & 16.2 & 57.0 & 43.0 \\
\hline $3 r d$ & 72.4 & 73.7 & 46.3 & 7.6 & 44.0 & 2.1 & 90.3 & 9.7 \\
\hline All & 45.6 & 92.7 & 38.9 & 16.9 & 28.4 & 15.7 & 67.3 & 32.7 \\
\hline
\end{tabular}

Tanypodinae were represented by at least 12 genera, comprising at least 51 species. Labrundinia was the richest in species, with at least 16 species. The genus is a large group, predominantly Neotropical, with immature stages inhabiting a variety of aquatic systems (Silva and Fonseca-Gessner, 2009; Silva et al., 2011, 2014c). Silva et al. (2015), based on phylogenetic inference, suggested that Labrundinia may have had its initial diversification in warmer waters in the Neotropical region and that current presence in the Nearctic region and southern South America is due to subsequent dispersal. Another commonly found Tanypodinae was Ablabesmyia; with 13 species, it was the most widespread tanypodine. Ablabesmyia is a remarkably species-rich genus of the Tanypodinae, composing one of the most distinctive and well-defined clade within the tribe Pentaneurini (Silva and Ekrem, 2016). The highest diversity of Ablabesmyia seems to be in the tropical and warm-temperate belts.

\section{Doubtful records}

Larvae of Labrundinia separata (Edwards) differ from other Labrundinia species by the surface of head capsule covered with spinules, lateroventral and posteroventral spine groups absent; subbasal seta of posterior parapod simple; bifid claw with V-shaped lower indentation (Silva et al., 2014c). So far, L. separata is distributed exclusively in southern South America in Argentina and Chile. During sampling in a small stream in Central-West Brazil, a fourth-instar larva fitting the diagnostic criteria of L. separata was collected. However, in absence of association between larval and adult specimens, this recorded is kept as doubtful. Similarly, larvae of L. pilosella (Loew) were collected at the same locality. This species is one of the most widespread within Labrundinia, with the distribution ranging from northern Canada to Central America. For the same reason as given for L. separata, the record of $L$. pilosella in Central-West Brazil is considered uncertain. However, based on its wider distribution, L. pilosella is likely to occur in South America.

\section{Molecular analyses}

Material suitable for genetic analyses was obtained for 120 specimens belonging to Ablabesmyia, Chironomus, Labrundinia and Polypedilum. The aligned COI sequences were 658 bp long with 300 variable sites (45.6\%), of which $278(92.7 \%)$ were potentially parsimony informative
(Table 3). Most variable sites occurred in the third codon position. The sequences were somewhat AT-biased, especially in the third position (Table 3). A NJ tree demonstrated that a substantial barcode divergence exists between all putative species. Bootstrap supports were $99 \%$ or higher for all species clusters.

Based on clustering of specimens in the NJ analysis, we were able to distinguish: 13 species of Ablabesmyia, 11 species of Chironomus, 15 species of Labrundinia and 27 species of Polypedilum. Maximum intraspecific divergence was observed in Chironomus sp. 1 (range: $3.5-5.3 \%$, average $4.4 \%$ ), followed by Polypedilum sp. 1 (range: 3.3-3.7\%, average 3.4\%), Polypedilum sp. $14(2.4 \%)$ and Labrundinia sp. $6(2.2 \%)$. The lowest interspecific distances were found between Chironomus sp. 10 and Chironomus sp. 11 (3.7\%), followed by Ablabesmyia sp. 2 and Ablabesmyia sp. 3 (range: 5.8-6.3\%, average 6.1\%), Ablabesmyia sp. 2 and Ablabesmyia sp. 4 (average 6.3\%), and Polypedilum sp. 6 and Polypedilum sp. 7 (6.4\%).

The specimens identified morphologically as Chironomus sp. 1 were divided into two distinct clusters, which may represent cryptic species. Nucleotide sequences of these specimens differed by a minimum of $3.4 \%$ and in up to 41 nucleotide sites, but there were no observable morphological characters that differentiated the specimens belonging to these clusters. Specimens of Chironomus sp. 1 allocated to each clusters were collected from five localities in Argentina and Chile (Table 2). The two groups exhibited geographical structure in the clustering, since they were collected in localities more than $750 \mathrm{~km}$ distant from each other.

Regarding the geographical variation among populations, a distinct phylogeographic pattern was detected. Ablabesmyia sp. 5 and sp. 6, both sampled from southern South America, clustered together and apart from those from northern South America. Similar patterns may be noticed in the specimens composing the cluster Chironomus sp. 1. Although geographical distribution in Polypedilum was not fully structured, DNA barcodes indicated that several species from southern South America represented close relatives (e.g., Polypedilum sp. 1, sp. 3 and sp. 4, and Polypedilum sp. 23 and sp. 24), not refuting the aforementioned pattern noted for Ablabesmyia and Chironomus (Fig. 2). Unfortunately, no information on geographical structuring could be inferred from Labrundinia. Up to now, L. separata Edwards is the only species recorded from southern South America. Here, L. separata was sampled solely in northern South America, as well as other Labrundinia, and its record remains doubtful (see above). 
(a)

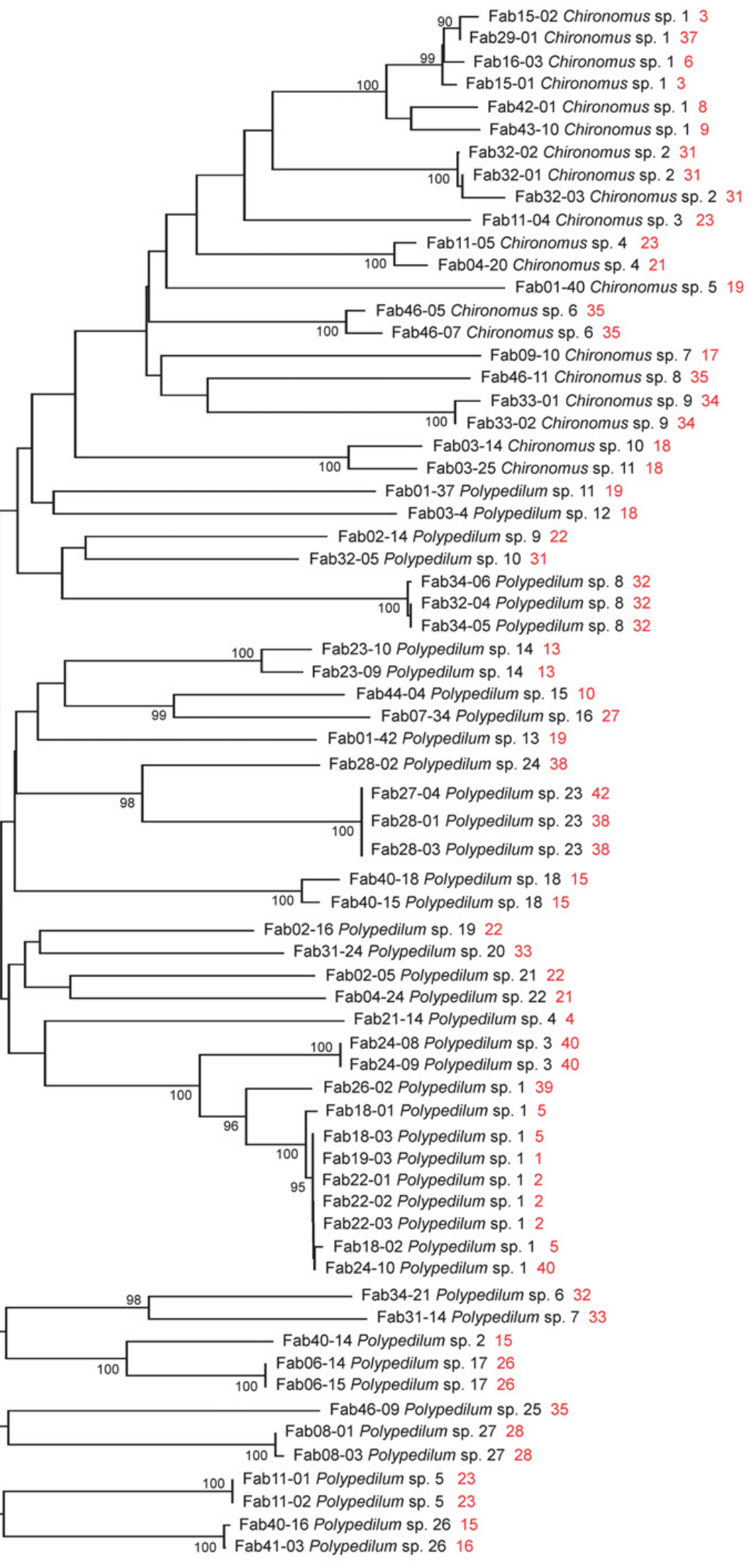

Fig. 2. NJ tree of the genera Ablabesmyia, Chironomus, Labrundinia and Polypedilum, based on partial COI sequences (DNA barcodes) and the K2P model. Numbers on branches are bootstrap values $>80 \%$. Red numbers indicate sampling localities. See Table 1 for more details. 


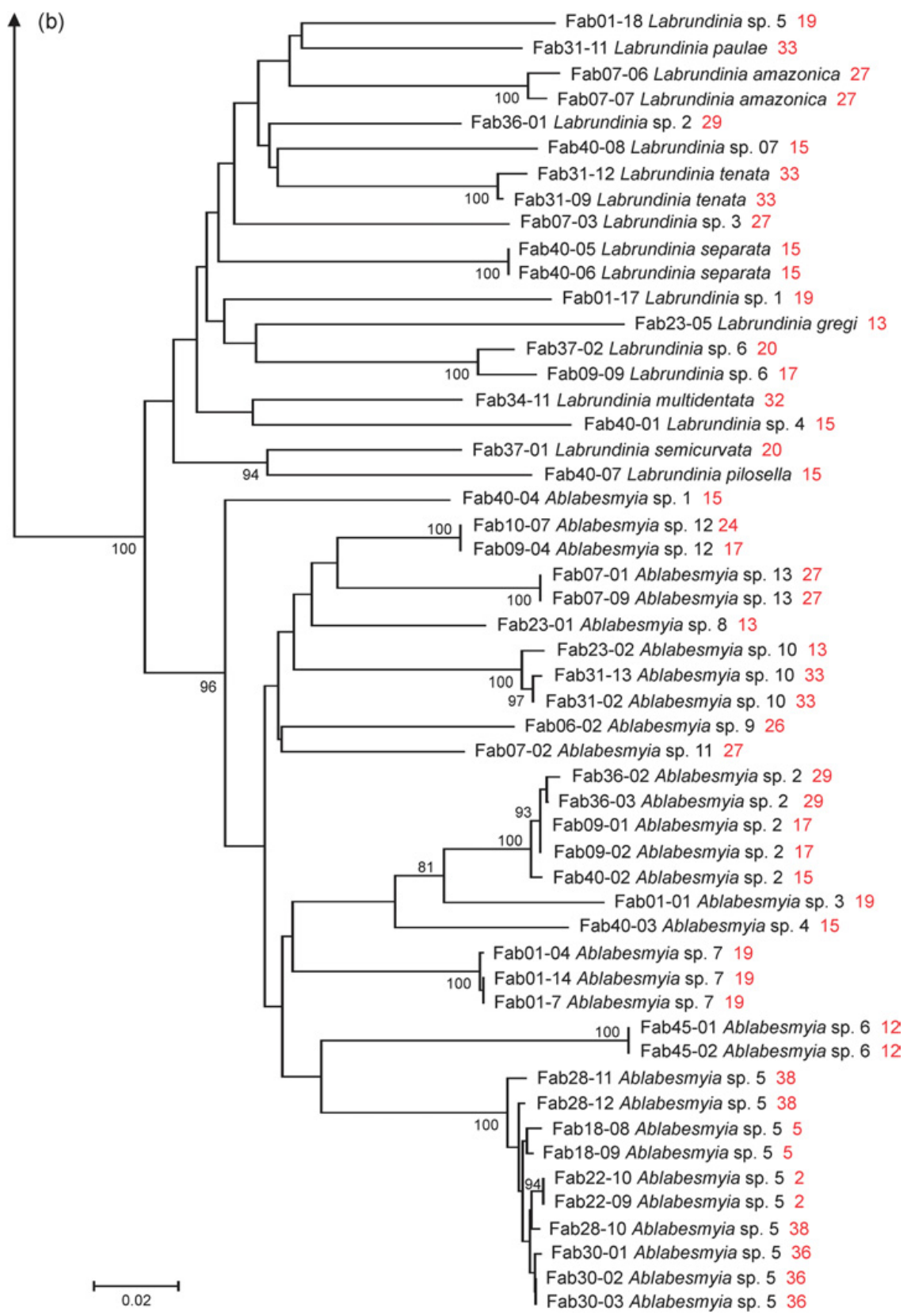

Fig. 2. Continued

\section{Discussion}

Biogeographers have documented similarity between the austral biotas for more than a century (e.g., Erichson, 1842; Cranston and Naumann, 1991), even before understanding how these patterns might have arisen (Krosch and Cranston, 2013). The vicariance model replaced a paradigm of successive colonization by dispersal from the north (Darlington, 1965). Regarding Chironomidae, the distribution of each subfamily, within its geographical range, is primarily driven by the availability of water ecologically suited to the requirements of the larvae (Oliver and Roussel, 1983). Nevertheless, in extreme environments, the ecological requirements of the adults seem to be the regulating factor in most of the cases. At the generic level, the chironomid fauna in South America includes multiple genera with worldwide distributions with Australian, Nearctic and Neotropical components. The Australian component is typically composed by a Gondwanan fauna found in Australia, New Zealand and southern South America, including primarily cold stenothermic rheophiles (e.g., Parochlus, Podonomus), which have not been able, for the most part, to cross the tropicaltemperate lowlands (Brundin, 1966). At the generic level, it is possible to infer that Apsectrotanypus, Botryocladius, Ferringtonia Nandeva, Parapsectrocladius, Parochlus, Podonomus and Riethia would represent an ancient Gondwanan group within the Chironomidae.

Numerous taxa within Chironomidae are considered to represent "classic" Gondwanan relicts (Krosch et al., 
2011). Lars Brundin recognized within the subfamilies Aphroteniinae, Diamesinae and Podonominae putative ancient groups with disjunct austral distributions (Brundin, 1963, 1966). Based on morphological data, Brundin reconstructed phylogenies for these hypothetical Gondwanan clades, which indicated congruent patterns of relationships among austral clades that were consistent with the geological consensus of the Gondwananbreakup (Brundin, 1965, 1966). Recently, taxonomic descriptions and generic revisions of non-biting midges belonging to the subfamily Orthocladiinae have recognized similar disjunct taxa (e.g., Barbadocladius, Botryocladius, Ferringtonia, Limnophyes and Pirara) of potential Gondwanan origin (Sæther, 1990; Boothroyd and Cranston, 1995; Cranston and Edward, 1999; Sæther and Andersen, 2010; Cranston and Krosch, 2011). Similar patterns may be expected among several groups from southernmost South America toward the temperatetropical tier, where Pan-American warm-adapted taxa may predominate.

The Neotropical region of South America comprises most of the continent, with the exception of the Andean portion (Amorim and Pires, 1996; Morrone, 1999, 2002). According to Halffter (1964, 1987), during the preQuaternary, the South American Neotropical biota expanded northward to Central America and Mexico, and southward to the South American transition zone and the Andean region (Morrone and Lopretto, 1994; Maury et al., 1996). In this regard, the Neotropical component includes a fauna occurring in lowlands, essentially warm-acclimated (Watson and Heyn, 1992), with either limnetic or rheophilic species (Reiss and Sublette, 1985). Within this component, genera such as Axarus, Beardius, Caladomyia, Coelotanypus, Djalmabatista, Goeldichironomus, Labrundinia, Lipurometriocnemus, Lopescladius, Nilothauma, Pentaneura and Polypedilum (Asheum) possess a Pan-American distribution, having secondarily dispersed into the southern Nearctic via Central America or the Caribbean (Reiss and Sublette, 1985). Endotribelos, Ichthyocladius, Oukuriella, Pelomus and Ubatubaneura have so far presented endemic distribution in the Neotropical region. The Nearctic component includes genera such as Cryptochironomus, Kiefferulus, Monodiamesa and Orthocladius, those taxa are highly diverse and widespread in the Holarctic region, and apparently dispersed into South America via the Antilles or Mexico. Ablabesmyia, Cladotanytarsus, Clinotanypus, Corynoneura, Chironomus, Cricotopus, Larsia, Polypedilum and Tanytarsus are examples of genera with worldwide distributions.

For a long time, most of the studies on South American entomofauna remained restricted to the Andean and Patagonian fauna (e.g., Edwards, 1931; Brundin, 1966; Reiss, 1972). Schuh and Stonedahl (1986) performed a cladistic biogeographic analysis of some plant bugs belonging to the family Miridae (Hemiptera). Their results recovered a general-area cladogram indicating two major biotic components, Laurasia and Gondwana. Within the first, a clade involves the Indo-Pacific (tropical Africa plus the Oriental region) and tropical America, while the latter one comprises the southern temperate areas (South Africa, southern South America and Australia). More recently, intercontinental relationships based on a biogeographic analysis of the Anisopodoidea (Diptera, Bibionomorpha) were proposed by Amorim and Tozoni (1994). In addition, Lamas et al. (2014) found evidence that an ancient Caribbean event was mainly responsible for the diversification of major lineages of Heterostylum (Diptera: Bombyliidae).

Here we tried to sample in as many different localities and aquatic systems as possible. We also visited some of the most neglected areas in terms of chironomid studies, as well as other Diptera, such as northeast and northwest Brazil. However, due to the limited duration and extension, we believe that the species richness documented here represents only a small range of the true richness of chironomid fauna in South America. A further limitation stems from the incomplete knowledge of the full life history, which, associated with the lack of descriptions and keys to a local fauna, prevents species identifications. Comparing our results with Spies and Reiss (1996), who catalogued roughly 110 genera in the Neotropical Region, we found more than half of the forms recorded at that time in the continent. It is expected that further collecting campaigns will find some widespread Neotropical genera, for example Antilocladius, Fissimentum, Procladius, Stictocladius, Tanypus, Zavreliella and Zavrelimyia, surprisingly not collected at this time.

The advantage of working with megadiverse taxa is that they most likely exhibit many repeated patterns, which may provide evidence of underlying processes (Coscaron et al., 2009). Genera such as Ablabesmyia, Chironomus, Labrundinia and Polypedilum, examined here in detail, are largely widespread and rich in species, and, therefore, may be considered as megadiverse. However, as a result of this greater diversity, their adult identification, based mostly on genitalic structures, is usually challenging and demands time-consuming genitalic dissections. Moreover, the identification of adults of the Chironomidae is very often further complicated by a lack of diagnostic morphological features to distinguish several species. Additionally, identification of some species can be achieved only by individual rearing of larvae and collecting larval and pupal skins to establish the associations between life stages (Silva and Wiedenbrug, 2014). In this context, DNA barcodes seem to be particularly useful for taxonomic groups that are diverse and difficult to identify using morphology (Hebert et al., 2004; Krosch and Cranston, 2013; Silva et al., 2013).

Partial COI gene sequences have been shown to be appropriate to delimit and identify species, as well as associate life stages in Chironomidae (Carew et al., 2003; Ekrem et al., 2007, 2010). In the Neotropical region, DNA barcoding has been used successfully for species delimitation and solving taxonomic conflicts in the Corynoneura group (Orthocladiinae), from the Atlantic Forest, Brazil (Silva and Wiedenbrug, 2014). In addition, Silva et al. (2013) were able to associate different life stages and 
delimitate species of Labrundinia (Tanypodinae) using the standard barcode fragment of COI amplified with the universal primers. Taking into account a biogeographic framework, the inclusion of molecular data into rigorous analyses permits biogeographers to create statistically testable hypotheses of dispersal and range expansion within the hypothetico-deductive framework (Mantooth and Riddle, 2011). Despite this advantage, there are some drawbacks regarding the use of DNA barcodes in biogeographic analyses. Cryptic speciation, high intraspecific nucleotide diversity and/or population structuring driven by geographical or biological factors may generate differences in DNA barcodes (Carew and Hoffmann, 2015). For example, processes such as incomplete mitochondrial lineage sorting may cause DNA barcodes to become dissociated with species divergences established by morphology and/or nuclear sequences (Alexander et al., 2009; Dai et al., 2012).

Our results support DNA-barcoding as an excellent tool for species delimitation in groups where taxonomy by means of morphology is challenging or even impossible. Regardless of the promising results, the inclusion of multiple nuclear sequences (Carew and Hoffmann, 2015) and further collections, considering the geographic and ecological landscapes from which sequences were previous sampled, coupled with the relationships among lineages, are valuable for species delimitation and may strengthen results, making it easier to classify the uniqueness of populations and species (Mantooth and Riddle, 2011).

\section{Conclusions}

Although our results document a considerable chironomid diversity in South America, we believe that sampling in different periods (including both the rainy and dry seasons) and broadening the variety of habitats and geographic area will reveal much greater numbers of species than currently detected. While efforts to detect and describe the diversity of the chironomid fauna in South America have increased lately, knowledge of their biology and ecology, as well as their biogeography and phylogeny, remains fragmentary and incomplete. Thus, additional inventories are required to obtain robust estimates of local species richness, and discover and analyze possible areas of endemism in the Neotropical region. Moreover, future chironomid inventories should also allocate more sampling effort to collecting floating pupal exuviae; this technique has been proven to provide a simple and safe means of obtaining abundant and reliable data on diversity. Furthermore, trace DNA has been successfully extracted from pupal skins, which increases the effectiveness of pupal exuviae as a resource in biodiversity monitoring and conservation programs (Krosch and Cranston, 2012; Kranzfelder et al., 2016). Finally, the most promising aspect of DNA barcoding is that it constitutes an effective union between the goals of systematists, biogeographers and ecologists. For purposes of conservation biogeography, DNA barcoding will likely have its greatest impact by filling in some of the details of species diversity in lesserknown and morphologically enigmatic taxa, and distributions of taxa.

Acknowledgements. We would like to thank Martin Spies, Sofia Wiedenbrug, Susan Gresens, Susana Trivinho Strixino and Xiaolong Lin for helping us to identify several species. We are very grateful to Gilberto Gonçalves Rodrigues and Neusa Hamada who enabled us to carry out field work in Recife and the Amazon Rainforest, respectively. We are greatly indebted to Ana Maria Oliveira Pes and Galileu Petronilo da Silva Dantas for providing us with material from Rio Grande do Sul and Roraima, respectively. Many thanks also to Whit Farnum for the assistance in the preparation of the map. We are also very grateful to Torbjørn Ekrem for useful comments and valuable suggestions during the initial phase of this study. Two reviewers offered valuable comments on this manuscript. Collecting in South America was partly possible thanks to the generosity of George Putnam, through a Putnam expedition Grant from the Museum of Comparative Zoology at Harvard University. F. L. da Silva was supported by a Postdoctoral Fellowship from the Coordination for the Improvement of Higher Education Personnel (CAPES).

\section{References}

Alexander L.C., Delion M., Hawthorne D.J., Lamp W.O. and Funk D.H., 2009. Mitochondrial lineages and DNA barcoding of closely related species in the mayfly genus Ephemerella (Ephemeroptera: Ephemerellidae). J. North Am. Benthol. Soc., 28, 584-595.

Amorim D.S. and Pires M.R.S., 1996. Neotropical biogeography and a method for maximum biodiversity estimation. In: Bicudo C.E.M. and Menezes N.A. (eds.), Biodiversity in Brazil: a First Approach, CNPq, São Paulo, 183-219.

Amorim D.S. and Tozoni S.H.S., 1994. Phylogenetic and biogeographic analysis of the Anisopodoidea (Diptera, Bibionomorpha), with an area cladogram for intercontinental relationships. Rev. Bras. Entomol., 38, 517-543.

Andersen T., 1996. A new species of Monodiamesa Kieffer, 1922 from Southern Chile (Diptera: Chironomidae: Prodiamesinae). Rev. Chil. Entomol., 23, 43-49.

Andersen T. and Pinho L.C., 2014. A new Thalassosmittia Strenzke and Remmert, 1957 out of the sea: T. amazonica n. sp. from the Amazon Rainforest, Brazil (Diptera: Chironomidae, Orthocladiinae). Chironomus Newsl. Chironomid. Res., 27, 25-30.

Andersen T., Ekrem T. and Cranston P.S., 2013a. The larvae of the Holarctic Chironomidae - introduction. In: Andersen T., Cranston P.S. and Epler J.H. (eds.), The Larvae of Chironomidae (Diptera) of the Holarctic Region - Keys and Diagnoses. Insect Systematics \& Evolution, Scandinavian Entomology, Lund, Sweden, 7-12.

Andersen T., Ekrem T. and Cranston P.S., 2013b. The Larvae of Chironomidae (Diptera) of the Holarctic Region - Keys and Diagnoses. Insect Systematics \& Evolution, Scandinavian Entomology, Lund, Sweden, 571 p.

Andersen T., Pinho L.C. and Mendes H.F., 2016. Two new species of Lipurometriocnemus Sæther from Brazil (Diptera: Chironomidae, Orthocladiinae). Biotemas, 29, 37-45. 
Armitage P.D., Cranston P.S. and Pinder L.C.V., 1995. The Chironomidae. Biology and Ecology of Non-biting Midges, Chapman \& Hall, London, 571 p.

Ashe P. and Cranston P.S., 1990. Chironomidae. In: Soos A. and Papp L. (eds.), Catalogue of Palaearctic Diptera, Elsevier Science Publishers, Amsterdam, The Netherlands, 113-355.

Ashe P. and O'Connor J.P., 2009. A World Catalogue of Chironomidae (Diptera). Part 1. Buchonomyiinae, Chilenomyiinae, Podonominae, Aphroteniinae, Tanypodinae, Usambaromyiinae, Diamesinae, Prodiamesinae and Telmatogetoninae, Irish Biogeographical Society \& National Museum of Ireland, Dublin, 445 p.

Ashe P., Murray D.A. and Reiss F., 1987. The zoogeographical distribution of Chironomidae (Insecta: Diptera). Ann. Limnol., 23, 27-60.

Boothroyd I.K.G. and Cranston P.S., 1995. Two Orthocladiinae (Chironomidae) genera common to New Zealand and Australia: Pirara n. gen. and Eukiefferiella Thienemann. In: Cranston P.S. (ed.), Chironomids: from Genes to Ecosystems, CSIRO, Melbourne, 389-408.

Brumfield R.T. and Capparella A.P., 1996. Historical diversification of birds in north-western South America: a molecular perspective on the role of vicariant events. Evolution, 50, 1607-1624.

Brundin L., 1963. Limnic Diptera in their bearings on the problem of transantarctic faunal connections. In: Gressitt J.L. (ed.), Pacific Basin Biogeography, a Symposium, Bishop Museum Press, Honolulu, Hawaii, 425-434.

Brundin L., 1965. On the real nature of transantarctic relationships. Evolution, 19, 496-505.

Brundin L., 1966. Transantarctic relationships and their significance, as evidenced by chironomid midges. With a monograph of the subfamilies Podonominae and Aphroteniinae and the austral Heptagyiae. K. Sven. Vetensk. Akad. Handl., 11, 1-474.

Carew M.E. and Hoffmann A.A., 2015. Delineating closely related species with DNA barcodes for routine biological monitoring. Freshw. Biol., 60, 1545-1560.

Carew M.E., Pettigrove V. and Hoffmann A.A., 2003. Identifying chironomids (Diptera: Chironomidae) for biological monitoring with PCR-RFLP. Bull. Entomol. Res., 93, 483-490.

Conti E., Eriksson T., Schönenberger J., Sytsma K.J. and Baum D.A., 2002. Early Tertiary out-of-India dispersal of Crypteroniaceae: evidence from phylogeny and molecular dating. Evolution, 56, 1931-1942.

Correia L.C.S. and Trivinho-Strixino S., 2005. New records of Chironomus Meigen, 1803 (Chironomidae, Diptera) in the State of São Paulo (Brazil). Rev. Bras. Entomol., 49, 430-433.

Correia L.C.S. and Trivinho-Strixino S., 2007. New species of Chironomus Meigen (Diptera: Chironomidae: Chironominae) from Brazil. Zootaxa, 1504, 53-68.

Correia L.C.S., Trivinho-Strixino S. and Michailova P., 2005. A new species of Chironomus Meigen, 1803 (Diptera, Chironomidae) from the southeast of Brazil. Stud. Neotrop. Fauna Environ., 40, 29-38.

Correia L.C.S., Trivinho-Strixino S. and Michailova P., 2006. A new species of Chironomus Meigen (Diptera: Chironomidae: Chironominae) from polluted streams of the southeastern Brazil. Zootaxa, 1130, 5768.
Correia L.C.S., Trivinho-Strixino S. and Michailova P., 2013. Chironomus amissum sp. n. (Diptera, Chironomidae) from southeastern Brazil. Biota Neotrop., 13, 133-138.

Coscaron M.C., Melo M.C., Coddington J. and Corronca J., 2009. Estimating biodiversity: a case study on true bugs in Argentinian wetlands. Biodivers. Conserv., 18, 1491-1507.

Cranston P.S. and Edward D.H.D., 1999. Botryocladius gen. n.: a new transantarctic genus of orthocladiine midge (Diptera: Chironomidae). Syst. Entomol., 24, 305-333.

Cranston P.S. and Krosch M.N., 2011. Barbadocladius Cranston and Krosch, a new genus of Orthocladiinae (Diptera: Chironomidae) from South America. Neotrop. Entomol., 40, 60-67.

Cranston P.S. and Naumann I.D., 1991. Biogeography. In: Naumann I.D. (ed.), Insects of Australia: a Textbook for Students and Research Workers, CSIRO Division of Entomology, Melbourne University Press, Carlton, Victoria, 181-197.

Cranston P.S., Oliver D.R. and Sæther O.A., 1989. Keys and diagnoses of the adult males of the subfamily Orthocladiinae (Diptera, Chironomidae). In: Wiederholm T. (ed.), Chironomidae of the Holarctic Region. Keys and Diagnoses. Adult Males, Entomol. Scand. Suppl., 34, 165-352.

Cranston P.S., Hardy N.B., Morse G.E., Puslednik L. and Mccluen S.R., 2010. When molecules and morphology concur: the 'Gondwanan' midges (Diptera: Chironomidae). Syst. Entomol., 35, 636-648.

Dai Q.-Y., Gao Q., Wu C.-S., Chesters D., Zhu C.-D. and Zhang A.-B., 2012. Phylogenetic reconstruction and DNA barcoding for closely related pine moth species (Dendrolimus) in China with multiple gene markers. PLoS ONE, 7, e32544.

Dantas G.P.S. and Hamada N., 2013. Two new species of Fittkauimyia Karunakaran (Diptera: Chironomidae) from Brazil. Zootaxa, 3681, 573-582.

Darlington P.J. Jr., 1965. Biogeography of the Southern End of the World, Harvard University Press, Cambridge, 236 p.

Darwin C., 1859. On the Origin of Species by Means of Natural Selection, John Murray, London.

Drummond A.J., Ashton B., Cheung M., Heled J., Kearse M., Moir R., Stones-Havas S., Thierer T. and Wilson A.C., 2010. Geneious v 8.0.5 Biomatters. Available online at: http://www.geneious.com/web/geneious/geneious-versions [accessed 22 September 2015].

Edgar R.C., 2004. MUSCLE: multiple sequence alignment with high accuracy and high throughput. Nucleic Acids Res., 32, 1792-1797.

Edwards F.W., 1931. Part II. Fascicle 5. Chironomidae. In: Trustees of the British Museum (ed.), Diptera of Patagonia and South Chile, British Museum, London, 233-331.

Ekrem T. and Reiss F., 1999. Two new Tanytarsus species (Diptera: Chironomidae) from Brazil, with reduced median volsella. Aquat. Insects, 21, 205-213.

Ekrem T., Willassen E. and Stur E., 2007. A comprehensive DNA library is essential for identification with DNA barcodes. Mol. Phylogenet. Evol., 43, 530-542.

Ekrem T., Stur E. and Hebert P.D.N., 2010. Females do count: documenting Chironomidae (Diptera) species diversity using DNA barcoding. Org. Divers. Evol., 10, 397-408.

Epler J.H., 2001. Identification Manual for the Larval Chironomidae (Diptera) of North and South Carolina: a 
Guide to the Taxonomy of the Midges of the Southeastern United States, Including Florida, North Carolina Department of Environment and Natural Resources and St. Johns River Water Management District, Raleigh and Palatka, USA, $526 \mathrm{p}$.

Epler J.H., Ekrem T. and Cranston P.S., 2013. The larvae of Chironominae (Diptera: Chironomidae) of the Holarctic region - keys and diagnoses. In: Andersen T., Cranston P.S. and Epler J.H. (eds.), The Larvae of Chironomidae (Diptera) of the Holarctic Region - Keys and Diagnoses. Insect Systematics \& Evolution, Scandinavian Entomology, Lund, Sweden, 387-556.

Erichson W.F., 1842. Beitrag zur Fauna von Vandiemensland mit besonderer Rucksicht auf die Geographische Verbreitung der Insekten. Wiegmann's Arch., 8, 83-287.

Felsenstein J., 1985. Confidence limits on phylogenies: an approach using the bootstrap. Evolution, 39, 783-791.

Ferrington L.C. Jr., 2008. Global diversity of non-biting midges (Chironomidae; Insecta-Diptera) in freshwater. Hydrobiologia, 595, 447-455.

Ferrington L.C. Jr., Berg M.B. and Coffman W.P., 2008. Chironomidae. In: Merritt R.W., Cummins K.W. and Berg M.B. (eds.), An Introduction to the Aquatic Insects of North America, Kendall/Hunt Publishing Co., Dubuque, Iowa, USA, 847-989.

Fittkau E.J., Illies J., Klinge H., Schwabe G.H. and Sioli H., 1969. Biogeography and Ecology in South America, Junk, The Hague, xxviii $+946 \mathrm{p}$.

Folmer O., Black M., Hoeh W., Lutz R. and Vrijenhoek R., 1994. DNA primers for amplification of mitochondrial cytochrome c oxidase subunit I from diverse metazoan invertebrates. Mol. Mar. Biol. Biotechnol., 3, 294-299.

Freeman P., 1959. A study of the New Zealand Chironomidae (Diptera, Nematocera). Bull. Br. Mus. Nat. Hist. Entomol., 7, 393-437.

Freeman P., 1961. The Chironomidae (Diptera) of Australia. Aus. J. Zool., 9, 611-737.

Funk V.A., 2004. Revolutions in historical biogeography. In: Lomolino M.V., Sax D.F. and Brown J.H. (eds.), Foundations of Biogeography: Classic Papers with Commentaries, University of Chicago Press, Chicago and London, 647-657.

Halffter G., 1964. La entomofauna americana, ideas acerca de su origen y distribucíon. Folia Entomol. Mex., 6, $1-108$.

Halffter G., 1987. Biogeography of the montane entomofauna of Mexico and Central America. Annu. Rev. Entomol., 32, 95-114.

Hebert P.D.N., Penton E.H., Burns J.M., Janzen D.H. and Hallwachs W., 2004. Ten species in one: DNA barcoding reveals cryptic species in the Neotropical skipper butterfly Astraptes fulgerator. Proc. Natl. Acad. Sci. USA, 101, 14812-14817.

Hooker J.D., 1843. The Botany of the Antarctic Voyage of H.M. Discovery Ships Erebus and Terror in the Years 1839-1843. II. Flora Antartica.

Kimura M., 1980. A simple method for estimating evolutionary rates of base substitutions through comparative studies of nucleotide sequences. J. Mol. Evol., 16, 111-120.

Klicka J.T. and Zink R.M., 1997. The importance of recent ice ages in speciation: a failed paradigm. Science, 277, $1666-1669$.
Kranzfelder P., Ekrem T. and Stur E., 2016. Trace DNA from insect skins: a comparison of five extraction protocols and direct PCR on chironomid pupal exuviae. Mol. Ecol. Resour., 16, 353-363.

Krosch M.N. and Cranston P.S., 2012. Non-destructive DNA extraction from Chironomidae, including of fragile pupal exuviae, extends analyzable collections and enhances vouchering. Chironomus Newsl., 25, 22-27.

Krosch M.N. and Cranston P.S., 2013. Not drowning, (hand) waving? Molecular phylogenetics, biogeography and evolutionary tempo of the 'Gondwanan' midge Stictocladius Edwards (Diptera: Chironomidae). Mol. Phylogenet. Evol., 68, 595-603.

Krosch M.N., Baker A.M., Mather P.B. and Cranston P.S., 2011. Systematics and biogeography of the Gondwanan Orthocladiinae (Diptera: Chironomidae). Mol. Phylogenet. Evol., 59, 458-468.

Kumar S., Stecher G. and Tamura K., 2016. MEGA7: molecular evolutionary genetics analysis version 7.0. Mol. Biol. Evol., 33, 1870-1874.

Lamas C.J.E., Nihei S.S., Cunha A.M. and Couri M., 2014. Phylogeny and biogeography of Heterostylum Macquart (Diptera, Bombyliidae): evidence for an ancient Caribbean diversification model. Florida Entomol., 97, 952-966.

Mantooth S. and Riddle B.R., 2011. Molecular biogeography: the intersection between geographic and molecular variation. Geogr. Compass, 1-20.

Maury E.A., Pinto da Rocha R. and Morrone J.J., 1996. Distribution of Acropsopilio chilensis Silvestri, 1904, in southern South America (Opiliones, Palpatores, Caddidae). Biogeographica, 72, 127-132.

Morrone J.J., 1999. Presentación preliminary de un nuevo esquema biogeográfico de América del Sur. Biogeographica, $75,1-16$.

Morrone J.J., 2002. Biogeographic regions under track and cladistic scrutiny. J. Biogeogr., 29, 149-152.

Morrone J.J. and Lopretto E.C., 1994. Distributional patterns of freshwater Decapoda (Crustacea: Malacostraca) in southern South America: a panbiogeographic approach. J. Biogeogr., 21, 97-109.

Neubern C.S.O., Trivinho-Strixino S. and Silva F.L., 2011. Riethia manauara n. sp., an Amazonian chironomid (Diptera: Chironomidae) from Brazil. Neotrop. Entomol., 40, 595-599.

Oliveira C.S.N. and Silva F.L., 2011. Two new species of Larsia Fittkau, 1962 (Chironomidae: Tanypodinae) from Neotropical Region, with a checklist of Larsia species of the world. Zootaxa, 2786, 27-41.

Oliver D.R. and Roussel M.E., 1983. The genera of larval midges of Canada. In: The Insects and Arachnids of Canada, Part 2, Biosystematics Research Institute, Ottawa, 263 p.

Ospina-Torres R., 1992. Die Chironomidenfauna zentral-amazonischer Waldbäche. PhD thesis, LudwigMaximilians-Universität, Munich, Vol. I, 377 p./Vol. II, $221 \mathrm{p}$.

Page R.D.M., 1996. TREEVIEW: an application to display phylogenetic trees on personal computers. CABIOS, 12, 357-358.

Pinder L.C.V., 1986. The pupae of Chironomidae (Diptera) of the Holarctic region - introduction. In: Wiederholm T. (ed.), Chironomidae of the Holarctic Region. Keys and Diagnoses. Pupae, Entomol. Scand. Suppl., 28, 5-7. 
Pinder L.C.V., 1989. The adult males of Chironomidae (Diptera) of the Holarctic region - introduction. In: Wiederholm T. (ed.), Chironomidae of the Holarctic Region. Keys and Diagnoses. Adult Males, Entomol. Scand. Suppl., 34, 5-9.

Reiss F., 1972. Die Tanytarsini (Chironomidae, Diptera) Südchiles und Westpatagoniens. Mit Hinweisen auf die Tanytarsini-Fauna der Neotropis. Stud. Neotrop. Fauna Environ., 7, 49-94.

Reiss F. and Sublette J.E., 1985. Beardius, new genus with notes on additional Pan-American taxa. Spixiana Suppl., 11, 179-193.

Roque F.O., Correia L.C.S., Trivinho-Strixino S. and Strixino G., 2004. A review of Chironomidae studies in lentic systems in the state of São Paulo, Brazil. Biota Neotrop., 4, 1-19.

Sæther O.A., 1969. Some Nearctic Podonominae, Diamesinae, and Orthocladiinae (Diptera: Chironomidae), Department of Fisheries and Oceans, Ottawa, 154 p.

Sæther O.A., 1980. Glossary of chironomid morphology terminology (Diptera: Chironomidae). Entomol. Scand. Suppl., 14, $1-51$.

Sæther O.A., 1990. A review of the genus Limnophyes Eaton from the Holarctic and Afrotropical regions. Entomol. Scand. Suppl., 35, 1-135.

Sæther O.A., 2000. Phylogeny of the subfamilies of Chironomidae (Diptera). Syst. Entomol., 25, 393-403.

Sæther O.A. and Andersen T., 2010. Ferringtonia, a New Genus of Orthocladiinae from Patagonia and South Chile (Diptera: Chironomidae). In: Ferrington L.C. Jr. (ed.), Proceedings from the XV International Symposium on Chironomidae, Chironomidae Research Group, University of Minnesota, Saint Paul, Minnesota, 311-333.

Sæther O.A. and Ekrem T., 2003. Biogeography of afrotropical Chironomidae (Diptera), with special reference to Gondwanaland. Cimbebasia, 19, 175-191.

Sæther O.A., Andersen T., Pinho L.C. and Mendes H.F., 2010. The problems with Polypedilum Kieffer (Diptera: Chironomidae), with the description of Probolum subgen. n. Zootaxa, 2497, 1-36.

Sanseverino A.M. and Trivinho-Strixino S., 2010. New species of Tanytarsus van der Wulp (Diptera: Chironomidae) from São Paulo State, Brazil. Neotrop. Entomol., 39, 67-82.

Sanseverino A.M., Trivinho-Strixino S. and Nessimian J.L., 2010. Taxonomic status of Nimbocera Reiss, 1972, a junior synonym of Tanytarsus van der Wulp, 1874 (Diptera: Chironomidae). Zootaxa, 2359, 43-57.

Schuh R.T. and Stonedahl G.M., 1986. Historical biogeography in the Indo-Pacific: a cladistic approach. Cladistics, 2, 337355.

Silva F.L. and Ekrem T., 2016. Phylogenetic relationships of non-biting midges in the subfamily Tanypodinae (Diptera: Chironomidae) inferred from morphology. Syst. Entomol., $41,73-92$.

Silva F.L. and Fonseca-Gessner A.A., 2009. The immature stages of Labrundinia tenata (Diptera: Chironomidae: Tanypodinae) and redescription of the male. Zoologia, 26, 541-546.

Silva F.L. and Wiedenbrug S., 2014. Integrating DNA barcodes and morphology for species delimitation in the Corynoneura group (Chironomidae: Orthocladiinae). Bull. Entomol. Res., 104, 65-78.
Silva F.L., Trivinho-Strixino S. and Oliveira H.N., 2010. New species of Cryptochironomus Kieffer, 1918 (Diptera: Chironomidae: Chironominae) from Brazil. Zootaxa, 2614, 18-32.

Silva F.L., Fonseca-Gessner A.A. and Ekrem T., 2011. Revision of Labrundinia maculata Roback, 1971, a new junior synonym of L. longipalpis (Goetghebuer, 1921) (Diptera: Chironomidae: Tanypodinae). Aquat. Insects, 33, 293-303.

Silva F.L., Wiedenbrug S., Oliveira C.S.N., Trivinho-Strixino S. and Pepinelli M., 2012. Two new species of Hudsonimyia Roback, 1979 (Diptera: Chironomidae: Tanypodinae) from Neotropical Region unveiled by morphology and DNA Barcoding. J. Nat. Hist., 46, 1615-1638.

Silva F.L., Ekrem T. and Fonseca-Gessner A.A., 2013. DNA barcodes for species delimitation in Chironomidae (Diptera): a case study on genus Labrundinia. Can. Entomol., 145, 589-602.

Silva F.L., Oliveira C.S.N. and Trivinho-Strixino S., 2014a. Metapelopia corbii gen. n., sp. n., a new Tanypodinae (Diptera: Chironomidae) from the Neotropical Region. Ann. Limnol., 50, 85-95.

Silva F.L., Wiedenbrug S. and Oliveira C.S.N., 2014b. Denopelopia moema, a new Tanypodinae (Diptera: Chironomidae) from the Neotropical Region. Zootaxa, 3753, 297-299.

Silva F.L., Fonseca-Gessner A.A. and Ekrem T., 2014c. A taxonomic revision of genus Labrundinia Fittkau, 1962 (Diptera: Chironomidae: Tanypodinae). Zootaxa, 3769, 1-185.

Silva F.L., Ekrem T. and Fonseca-Gessner A.A., 2015. Out of South America: phylogeny of non-biting midges in the genus Labrundinia (Diptera: Chironomidae) suggests multiple dispersal events to Central and North America. Zool. Scr., 44, 59-71.

Siri A. and Donato M., 2015. Phylogenetic analysis of the tribe Macropelopiini (Chironomidae: Tanypodinae): adjusting homoplasies. Zool. J. Linn. Soc., 174, 74-92.

Spies M. and Reiss F., 1996. Catalog and bibliography of Neotropical and Mexican Chironomidae (Insecta, Diptera). Spixiana Suppl., 22, 61-119.

Spies M., Andersen T., Epler J.H. and Watson C.N. Jr., 2009. Chironomidae (non-biting midges). In: Brown B.V., Borkent A., Cumming J.M., Wood D.M., Woodley N.E. and Zumbado M. (eds.), Manual of Central American Diptera, NRC Research Press, Ottawa, 437-480.

Stelbrink B., Albrecht C., Hall R. and Rintelen T., 2012. The biogeography of Sulawesi revisited: is there evidence for a vicariant origin of taxa on Wallace's "anomalous island"? Evolution, 1-20.

Trivinho-Strixino S., 2014. Ordem Diptera. Família Chironomidae. Guia de identificação de larvas. In: Hamada N., Nessimian J.L. and Querino R.B. (eds.), Insetos Aquático na Amazônia Brasileira: taxonomia, biologia e ecologia, Editora do Instituto Nacional de Pesquisas da Amazônia, Manaus, 457-660.

Trivinho-Strixino S. and Silva F.L., 2011. A new species of Pelomus Reiss, 1989 (Diptera: Chironomidae: Chironominae) from the Neotropical Region, with emendation of the generic diagnosis. Aquat. Insects, 33, 273-279.

Trivinho-Strixino S., Silva F.L. and Oliveira C.S.N., 2013. Tapajos cristinae n. gen., n. sp. (Diptera: Chironomidae: 
Chironominae) from Neotropical Region. Zootaxa, 3710, 395-399.

Trivinho-Strixino S., Wiedenbrug S. and Silva F.L., 2015. New species of Tanytarsus van der Wulp (Diptera: Chironomidae: Tanytarsini) from Brazil. Eur. J. Environ. Sci., 5, 92-100.

Wallace A.R., 1876. The Geographical Distribution of Animals, Macmillans, London.

Watson C.N. Jr. and Heyn M.W., 1992. A preliminary survey of the Chironomidae (Diptera) of Costa Rica, with emphasis on the lotic fauna. Neth. J. Aquat. Ecol., 26, 257-262.

Wiedenbrug S., 2000. Studie zur Chironomidenfauna aus Bergbächen von Rio Grande do Sul, Brazilien. PhD thesis, Ludwig-Maximilians-Universität, Munich, 444 p.
Wiederholm T., 1986. Chironomidae (Diptera) of the Holarctic region. Keys and diagnoses. Part 2. Pupae. Entomol. Scand. Suppl., 28, 1-482.

Wiederholm T., 1989. Chironomidae (Diptera) of the Holarctic region. Keys and diagnoses. Part 1. Adult males. Entomol. Scand. Suppl., 34, 1-532.

Xiang Q.Y., Manchester S.R., Thomas D.T., Zhang W. and Fan C., 2005. Phylogeny, biogeography, and molecular dating of cornelian cherries (Cornus, Cornaceae): tracking tertiary plant migration. Evolution, 59, 1685-1700.

Zink R.M., 1996. Comparative phylogeography in North American birds. Evolution, 50, 308-317. 